\title{
Review on Sol-Gel Synthesis of Perovskite and Oxide Nanomaterials
}

\author{
Daniel Navas ${ }^{1}$, Sandra Fuentes ${ }^{2,3, *}$, Alejandro Castro-Alvarez ${ }^{4}$ (D) and Emigdio Chavez-Angel ${ }^{5, *}$ (D) \\ 1 Departamento de Química, Facultad de Ciencias Naturales, Matemática y del Medio Ambiente, Universidad \\ Tecnológica Metropolitana, Las Palmeras 3360, Ñuñoa, Santiago 7800003, Chile; daniel.navas@utem.cl \\ 2 Departamento de Ciencias Farmaceúticas, Facultad de Ciencias, Universidad Católica del Norte, Av. \\ Angamos 0610, Antofagasta 1270709, Chile \\ 3 Center for the Development of Nanoscience and Nanotechnology, CEDENNA, Av. Libertador Bernardo \\ O'Higgins 3363, Santiago 9160000, Chile \\ 4 Laboratorio de Bioproductos Farmacéuticos y Cosméticos, Centro de Excelencia en Medicina Traslacional, \\ Facultad de Medicina, Universidad de La Frontera, Av. Francisco Salazar 01145, Temuco 4780000, Chile; \\ alejandro.castro.a@ufrontera.cl \\ 5 Catalan Institute of Nanoscience and Nanotechnology (ICN2), CSIC and BIST, Campus UAB, Bellaterra, \\ 08193 Barcelona, Spain \\ * Correspondence: sfuentes@ucn.cl (S.F.); emigdio.chavez@icn2.cat (E.C.-A.)
}

Citation: Navas, D.; Fuentes, S.; Castro-Alvarez, A.; Chavez-Angel, E. Review on Sol-Gel Synthesis of Perovskite and Oxide Nanomaterials. Gels 2021, 7, 275. https://doi.org/ $10.3390 /$ gels7040275

Academic Editor: Andrei Jitianu

Received: 3 November 2021

Accepted: 15 December 2021

Published: 18 December 2021

Publisher's Note: MDPI stays neutral with regard to jurisdictional claims in published maps and institutional affiliations.

Copyright: (c) 2021 by the authors. Licensee MDPI, Basel, Switzerland. This article is an open access article distributed under the terms and conditions of the Creative Commons Attribution (CC BY) license (https:// creativecommons.org/licenses/by/ $4.0 /)$.

\begin{abstract}
Sol-Gel is a low cost, well-established and flexible synthetic route to produce a wide range of micro- and nanostructures. Small variations in $\mathrm{pH}$, temperature, precursors, time, pressure, atmosphere, among others, can lead to a wide family of compounds that share the same molecular structures. In this work, we present a general review of the synthesis of $\mathrm{LaMnO}_{3}, \mathrm{SrTiO}_{3}, \mathrm{BaTiO}_{3}$ perovskites and zinc vanadium oxides nanostructures based on Sol-Gel method. We discuss how small changes in the parameters of the synthesis can modify the morphology, shape, size, homogeneity, aggregation, among others, of the products. We also discuss the different precursors, solvents, working temperature, reaction times used throughout the synthesis. In the last section, we present novel uses of Sol-Gel with organic materials with emphasis on carbon-based compounds. All with a perspective to improve the method for future applications in different technological fields.
\end{abstract}

Keywords: Sol-Gel; nanoparticles; perovskites; metal oxides

\section{Introduction}

Sol-Gel method is one of the simplest techniques to synthesize high-quality nano and microstructures. This method provides several advantages over other synthesis routes such as control over the texture, size and surface properties of the materials, easy to implement, low cost, high quality, and production of materials with large surface areas [1]. This flexibility and simplicity make it very popular in the production of nanoscale powders [2-4] and its wide used as a coating method [5-7] (see Figure 1).

The first works on the Sol-Gel synthesis date from the mid-1800s with the pioneer studies of Ebelman [8] and Graham [9] on the fabrication of silica gels. The interest in gels grew very fast and notable researchers added their contributions to the field. Ostwald [10] and Lord Rayleigh [11] study the formation of Liesegang rings and the growth of crystals in gel potassium dichromate [12]. In the 1950s, Roy et al. extended its use and a large variety of ceramics were fabricated [13,14]. Years later, in the 1970s, Dislich presented new routes of synthesis of multicomponent oxide glasses [15] and the Sol-Gel method became a popular route to fabricate bulk glasses and ceramics. Since then, a number of researchers have contributed to the development of the Sol-Gel technology. A deep historical background of the Sol-Gel process and its evolution is presented by Sakka [16]. 


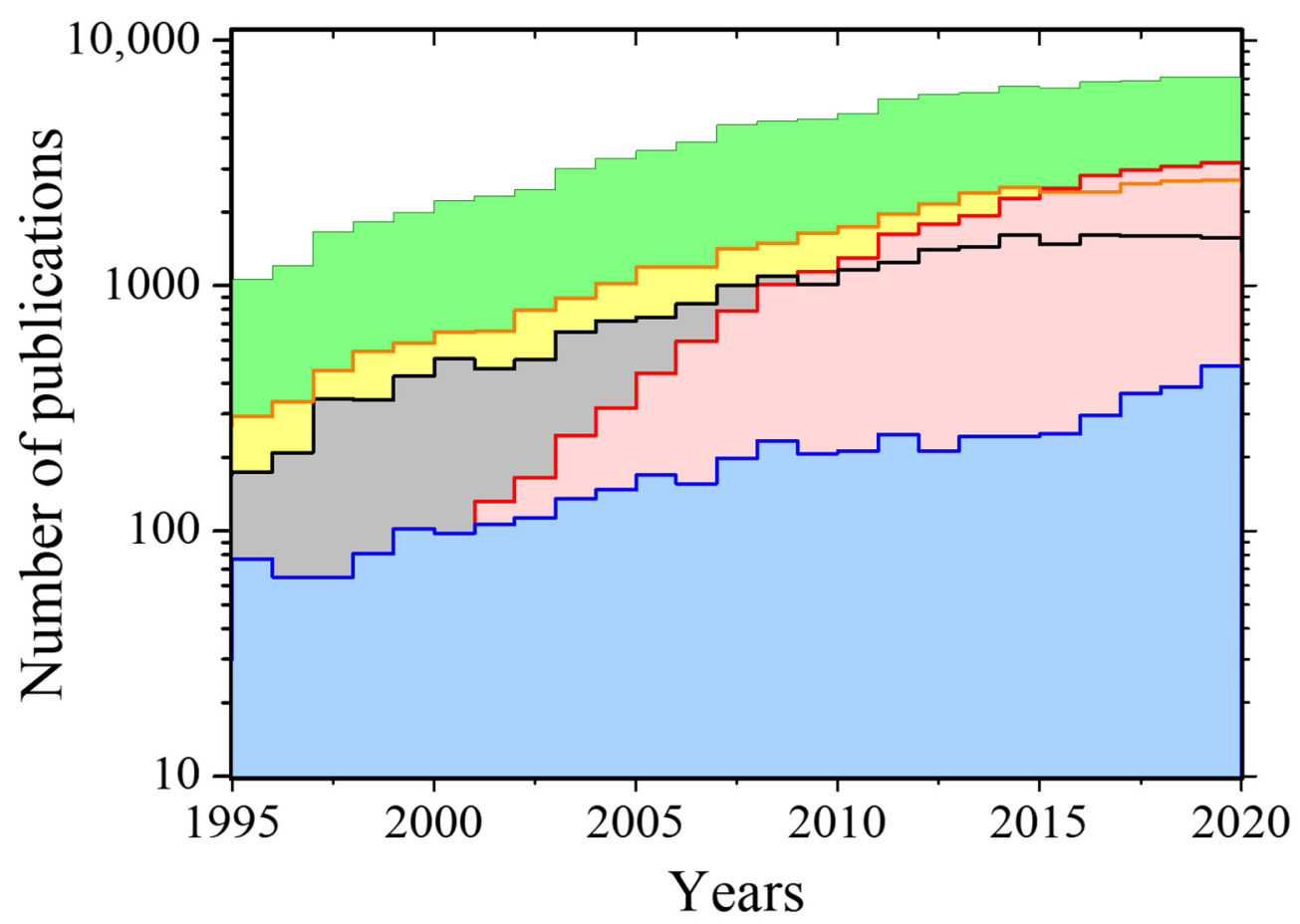

\begin{tabular}{|c|c|c|c|c|c|}
\hline Years & "Sol Gel” & + "Oxide" & +"Coating" & + “Nano" & + "Perovskite" \\
\hline 2020 & 6740 & 2522 & 1380 & 3201 & 429 \\
\hline 2019 & 7075 & 2692 & 1571 & 3166 & 469 \\
\hline 2018 & 7083 & 2664 & 1597 & 3061 & 387 \\
\hline 2017 & 6832 & 2605 & 1592 & 2957 & 364 \\
\hline 2016 & 6765 & 2413 & 1606 & 2809 & 295 \\
\hline 2015 & 6404 & 2403 & 1479 & 2500 & 248 \\
\hline 2014 & 6521 & 2515 & 1605 & 2271 & 243 \\
\hline 2013 & 6126 & 2387 & 1442 & 1932 & 243 \\
\hline 2012 & 6016 & 2156 & 1403 & 1784 & 212 \\
\hline 2011 & 5757 & 1960 & 1248 & 1630 & 247 \\
\hline 2010 & 5021 & 1735 & 1157 & 1296 & 212 \\
\hline
\end{tabular}

Figure 1. Top: Number of publications in the last 25 years including the keywords "Sol-Gel" (green), "Sol-Gel" + "oxide" (yellow), "Sol-Gel" + "coating" (grey), "Sol-Gel" + "nano" (red) and "Sol-Gel" + "perovskite" (blue). Bottom: table of number of publication in the with the number of publication in 2020-2010 period. All the data was extracted from web of science [17].

The Sol-Gel method involves the use of a colloidal solution (Sol) that evolves into a gel-like network including both a liquid and a solid phase as a result of several chemical reactions. It can be divided into two types: aqueous or hydrolytic and non-aqueous or non-hydrolytic. The aqueous Sol-Gel process can be described in five steps: hydrolysis, condensation, aging, drying and crystallization [18] (see Figure 2). 


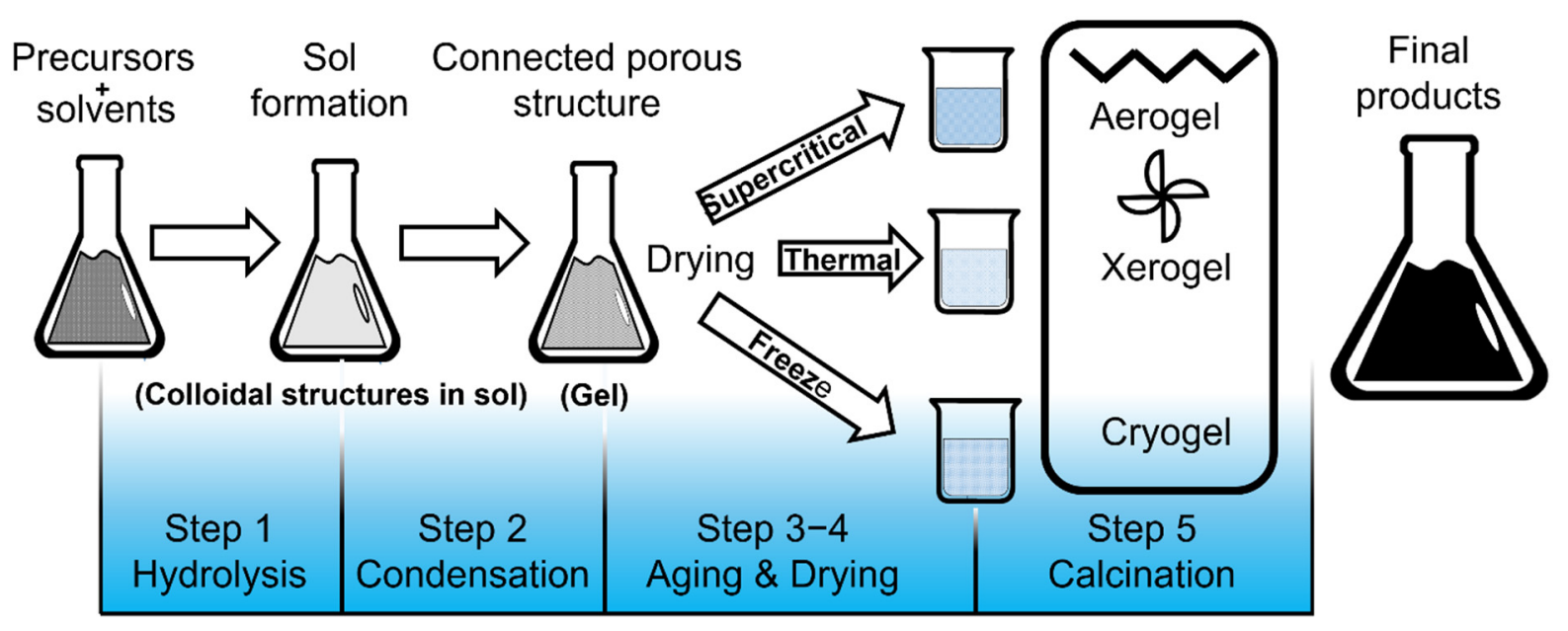

Figure 2. Schematic representation of step-by-step Sol-Gel method.

In the first step (hydrolysis) the metal alkoxide (MA) precursors and solvents are mixed. In this step, a nucleophilic attack takes place on MA by the oxygen from the water. As a result, simultaneous removal of alkoxide functional group and formation of alcohol functional group $(\mathrm{M}-\mathrm{OH})$ occurs. The hydrolysis and condensation reactions are strongly affected by process parameters such as the nature of the R-group, alkoxy functional group steric hindrance, temperature, $\mathrm{pH}$, use of aqueous or non-aqueous media or organic solvents like alcohols, the ratio of solvent to MA or acetylacetonates as precursors and the use and concentration of catalysts (acid or a base). All of these variables can make synthetic control difficult through this route. The structure of the resulting gel is significantly different depending on the catalyst. This is due to the relative rates of the hydrolysis and condensation reactions. In general, the hydrolysis step gets progressively slower under acidic conditions and faster under basic conditions [19].

The condensation or polycondensation step is associated to the formation of a polymer network made of metal oxides linkages as a result of the elimination of solvent (water or alcohol) to form a sol. This process increases the viscosity of the solution as the polymer network grows, forming a porous structure within the liquid phase (Gel). The general chemical reaction for the hydrolysis and condensation process is given below:

$$
\begin{gathered}
\mathrm{M}-\mathrm{OR}+\mathrm{H}_{2} \mathrm{O} \rightarrow \mathrm{MOH}+\mathrm{ROH} \text { (hydrolysis) } \\
\mathrm{MOH}+\mathrm{XO}-\mathrm{M} \rightarrow \mathrm{MOM}+\mathrm{XOH} \text { (condensation) }
\end{gathered}
$$

where $M=$ metal, $X=H$ or alkyl Group $\left(\mathrm{C}_{n} \mathrm{H}_{2 n+1}\right)$. During the aging step, polycondensation continues within the localized solution along with precipitation of the gel network, which decreases porosity and increases thickness between colloidal particles. Another important factor is physical treatment of the sol or gel. Something as simple as evaporation rate during gelation can have a substantial impact on gel structure. When the liquid is removed from the gel, major changes to the network structure may occur. If the structure is maintained, an aerogel is formed-on the contrary if the structure collapses, a xerogel is formed. If the liquid is removed at low temperatures the term cryogels is coined. The aerogel shows high pore volume and surface area and xerogel results in low surface area and pore volume. Heat treatment is also important for drying gels as well as removing surface hydroxyl groups, densifying the material to produce a ceramic monolith or converting to a crystalline material [1].

Compared with other methods, the Sol-Gel method has many unique advantages, e.g.,:

1. Possibility of obtaining special products such as powders, films or coatings, microspheres, fibers;

2. Obtaining new solids with improved properties; 
3. High purity and homogeneity of the materials obtained;

4. Saving energy during the process;

5. Full control over the particle size and morphology;

6. The solution and reaction step allows to incorporate easily, uniformly and quantitatively some trace elements, achieving a uniform doping at the molecular level.

7. Compared with the solid-phase reaction, the chemical reaction is simpler and only requires a lower synthesis temperature $\left(<220^{\circ} \mathrm{C}\right)$.

But also some disadvantages such as, e.g.,:

1. Very sensible to moisture;

2. Difficult to scale up;

3. Can include several steps and is a time-consuming process;

4. Dimension and volume changes during different steps.

\section{Synthesis of Perovskites}

Alkoxide, alkoxide-salt, and Pechini methods are the most popular Sol-Gel-based techniques used in the synthesis of perovskites. The Sol-Gel Pechini method (chelate poly esterification) became the most used due to its versatility in preparing perovskite membranes, depositing dielectric films for the production of capacitors and multicomponent oxide materials [20]. One of the most significant advantages of this process is its simplicity and the low-temperature precursor handling. This results in the fabrication of nanopowders with excellent purity and uniformity, as well as precise control of the final composition of the material. Pechini method is also a popular choice for the synthesis of various mixed oxides due to its capacity to combine chemicals (such as lactic, glycolic, citric, and EDTA acids) leading to the creation of polybasic acid chelates with dissolved cations [21]. Chelating agents are employed to prevent partial metal segregation in the final compound, which might occur as a result of various interactions between metal ions in the solution [22]. The polyesterification of chelates occurs when a polyhydroxy alcohol is added to the solution and heated, resulting in a cross-linked chain of metal atoms connected to organic radicals [14]. When two chelating agents work together to complex all metal ions, a precursor solution is formed with all metal ions entirely bound. As a result, a more stable chelate complex system develops and the polymerization is aided by the following addition of ethylene glycol, which enhances uniformity. This method tends to reduce metal segregation after decomposition under heat treatment settings. In the synthesis process and subsequent heat treatment, the ratio of metal precursors to chelating agents is critical. In theory, this ratio should be high enough to ensure that all metal ions are tightly bound to their structures and prevents precipitates in the solution.

The Sol-Gel Pechini method offers an excellent control over perovskite structure producing very homogeneous solutions. At temperatures near $1000{ }^{\circ} \mathrm{C}$, this approach results in the creation of pure crystal perovskite structure.

Using this method, Shlapa et al. [23] synthesized very homogenous $\mathrm{La}_{1-\mathrm{x}} \mathrm{Sr}_{\mathrm{x}} \mathrm{MnO}_{3}$ (with $0.23<x<0.25$ ) nanoparticles with a very narrow particle sizes distribution between $30-35 \mathrm{~nm}$. They reported that the precursor arises during the reaction between metal ions and organic compounds (citric acid and ethylene glycol) and pyrolysis of the resulting gel. The crystalline perovskite structure emerged in one step at around $600{ }^{\circ} \mathrm{C}$, and the level of crystallinity increased as the treatment temperature was increased.

Zhang et al. [24] studied a large variety of novel rare earth-doped $\left(\mathrm{Dy}^{3+}, \mathrm{Eu}^{3+}, \mathrm{Sm}^{3+}\right.$, $\mathrm{Tb}^{3+}, \mathrm{Yb}^{3+} / \mathrm{Er}^{3+}, \mathrm{Yb}^{3+} / \mathrm{Tm}^{3+}$, and $\left.\mathrm{Yb}^{3+} / \mathrm{Ho}^{3+}\right) \mathrm{La}_{4} \mathrm{Ti}_{3} \mathrm{O}_{12}$ perovskite-like structures. The as-synthesized phosphors exhibit characteristic down-conversion (DC) or up-conversion (UC) emissions corresponding to the rare earth activator ions upon UV or NIR excitation.

Lima et al. [25] investigated the preparation of red-emitting $\mathrm{LaAlO}_{3}: \mathrm{Eu}^{3+}$ and greenemitting $\mathrm{LaAlO}_{3}: \mathrm{Tb}^{3+}$ phosphors using a modified Pechini's synthesis and sorbitol as polyalcohol chelating agents. The authors showed that the use of sorbitol as polyalcohol instead of ethylene glycol increases luminescence. A comparison of the Sol-Gel and Sol-Gel Pechini method is given in Table 1. 
Table 1. Main characteristic of methods for synthesis by Sol-Gel.

\begin{tabular}{ccccccc}
\hline $\begin{array}{c}\text { Synthesis } \\
\text { Methods }\end{array}$ & $\begin{array}{c}\text { Particle } \\
\text { Size }\end{array}$ & Agglomeration & Purity & Precursors & $\begin{array}{c}\text { Calcination } \\
\text { Temperature }\end{array}$ & Observations \\
\hline Sol-Gel & $>10 \mathrm{~nm}$ & Moderate & Excellent & $\begin{array}{c}\text { Alkoxide or } \\
\text { Acetylacetonates }\end{array}$ & $80{ }^{\circ} \mathrm{C}$ & $\begin{array}{c}\text { Obtaining of uniform and } \\
\text { small sized powders }\end{array}$ \\
\hline $\begin{array}{l}\text { Sol-Gel } \\
\text { Pechini }\end{array}$ & $>10 \mathrm{~nm}$ & Moderate & Excellent & Nitrates & $800-1000{ }^{\circ} \mathrm{C}$ & $\begin{array}{c}\text { Accurate control of the } \\
\text { final material composition }\end{array}$ \\
\hline
\end{tabular}

Recently, Osman et al. [26] reported the preparation of $\mathrm{Y}^{3+}$ doped $\mathrm{BaCe}_{0.54} \mathrm{Zr}_{0.36} \mathrm{Y}_{0.10} \mathrm{O}_{2.95}$ (BCZY) powders with various chelating agents as: citric acid, tartaric acid, glycolic acid, nitriloacetic acid, ethylenediaminetetraacetic acid and triethylenetetramine (TETA). The influence of the molecular weight of the chelating agent and functional group on thermal decomposition, phase formation and morphology of the samples were studied. The different types of chelating agents significantly affected the elemental composition, especially on $\mathrm{B}$ site of $\mathrm{ABO}_{3}$ perovskite structure of $\mathrm{BCZY}$. The prepared powders using chelating agents from carboxylic acid and polyamino carboxylic groups formed $\mathrm{Zr}$-cluster and Ce-cluster respectively, giving rise to the fluctuation in the calculated elemental mole fractions. The use of TETA in the synthesis minimized the formation of $\mathrm{BaCO}_{3}$, leading to the formation of high percentage of BCZY perovskite phase and homogeneous elemental composition. A summary of Pechini and conventional Sol-Gel method is shown in the Figure 3.

\section{Sol-Gel}

Reactant in solution $>$ Mix and Stirred $>$ Sol Formation $\quad \begin{array}{cc}\text { Sol drying } \\ \left(80^{\circ} \mathrm{C}\right)\end{array} \quad \begin{gathered}\text { Calcination } \\ 1000^{\circ} \mathrm{C}, 8 \mathrm{~h}\end{gathered}$

\section{Pechini}

$\begin{aligned} & \text { Metal Nitrite mix with } \\ & \text { citric acid }\end{aligned}>\begin{aligned} & \text { Solution mix with } \\ & \text { chelating agents }\end{aligned} \quad$ Resin formation $\quad \begin{gathered}\text { Calcination } \\ 800^{\circ} \mathrm{C}\end{gathered}$

Figure 3. Summary of steps for each perovskite synthesis method discussed.

\subsection{Sol-Gel Synthesis of Strontium and Barium Titanates and Its Derivate}

Strontium and barium titanates $\left(\mathrm{SrTiO}_{3}\right.$ and $\mathrm{BaTiO}_{3}$, respectively) are widely used in the industry and in medical areas. $\mathrm{BaTiO}_{3}$ is a low-cost ferroelectric material with a positive temperature coefficient, high dielectric constant and non-linear optical. It is also used as catalyst, microwave absorber and dielectric component of class II ceramic [27]. On the other hand, $\mathrm{SrTiO}_{3}$ is a well-known perovskite material for quantum paraelectricity with an unusually high dielectric constant [28]. $\mathrm{SrTiO}_{3}$ can be also found as a base material in highvoltage capacitors, voltage-dependent resistors and substrates for superconductors [29]. Despite the fact that $\mathrm{SrTiO}_{3}$ does not show ferroelectric properties at room temperature, it is possible to induce ferroelectric behavior by doping, substitution, among other factors. $\mathrm{SrTiO}_{3}$ and $\mathrm{BaTiO}_{3}$ and their derivates are very promising for gas sensing applications [30] and as n-type thermoelectric materials [31].

Size effects in nanostructured materials are of great importance from both fundamental considerations and practical applications. Initial research on size effects in ferroelectric materials has been mainly concentrated on $\mathrm{BaTiO}_{3}$ (BT). It is well-known that ferroelectricity properties strongly depend on its microstructure (crystallinity and grain size) and decreases with decreasing particle (grain) size, and disappears below a certain critical dimensions [32]. Then, the preparation methods play a critical role to define the desired properties. The traditional preparation methods of perovskite-type powders are performed by solid state reactions at high temperatures, usually higher than $1000{ }^{\circ} \mathrm{C}$, and under specific pressure and $\mathrm{pH}$ conditions. This method involves several stages, such as the mixing of the raw material, calcinations at high temperatures, washing, milling, classification, filtering, drying 
and sifting. However, it is difficult to control the morphology and size of particles of these materials causing a diminution or destruction of the ferroelectric behavior $[33,34]$.

Another approach is the synthesis in solution, where the titanates are prepared through coprecipitation and pyrolysis of metallo-organic precursors or through Sol-Gel processes. In general, the process uses titanium alkoxide and $\mathrm{Ba}$ (or $\mathrm{Sr}$ ) salts, with and without occurrence of organic species. The reaction modifies and stabilize cations agents preventing the accumulation of the particles $[35,36]$. The main advantages of this method are: low working temperatures, large control of the particle size (from 10 to $100 \mathrm{~nm}$ ) and the possibility of synthesize mixed oxide networks. However, starting products are expensive and the synthesis can be challenging.

The hydrothermal synthesis is another popular option, this method uses alkoxide or oxidizes as titanium source in presence of a salt from the alkaline-earth metal ion (halide, acetate, nitrate or hydroxide). The reaction occurs in alkaline conditions $(\mathrm{pH}=13-14)$ in a temperature range from $90{ }^{\circ} \mathrm{C}$ to $200{ }^{\circ} \mathrm{C}$. The main advantage of this method is that the experimental procedure is less complex and uses cheaper starting products than the Sol-Gel method. The main disadvantage of the hydrothermal method is that the titanates synthesized crystallize, mostly, in the metastable cubical phase which does not exhibit ferroelectric properties [37-40]. On the other hand, the use of water as reaction medium can also induce the incorporation of $\mathrm{OH}$ species to the $\mathrm{BaTiO}_{3}$ structure, which in turn leads to defects in the network $[32,41]$. These defects also modified the chemical stoichiometry and reduce the quality of the final products.

A popular way to produce these oxide titanates is by reaction of titanium $n$-butoxide $\left(\mathrm{Ti}\left(\mathrm{OC}_{4} \mathrm{H}_{9}\right)_{4}\right)$, tetrachloride $\left(\mathrm{TiCl}_{4}\right)$ or $\mathrm{TiOSO}_{4}$ with metal-nitrate $\mathrm{M}\left(\mathrm{NO}_{3}\right)_{2}$ [42], -chloride $\mathrm{MCl}_{2}$ [43] or -salts $\mathrm{M}(\mathrm{OH})_{2}$ [44] solutions (with $\mathrm{M}=\mathrm{Mg}, \mathrm{Ca}, \mathrm{Sr}, \mathrm{Ba}, \mathrm{Mn}$, etc.) through a Sol-Gel synthesis. In general oxides titanates are synthesized using Sol-Gel method to yield a crystalline material at much lower temperatures than usually required for solid-state reactions [45]. This method involves the use of hydrolysis to form gels from metal oxides before subjecting them to post processing to obtain high purity titanates.

Fuentes et al. [43] synthesized high-purity $\mathrm{BaTiO}_{3}$ (BT) using a Sol-Gel-hydrothermal reaction of $\mathrm{TiCl}_{4}$ and a $\mathrm{BaCl}_{2}$ solution in an oxygen atmosphere to obtain pseudo-tetragonal BT and particle sizes $<100 \mathrm{~nm}$. The authors studied the effect of temperature $\left(70-220^{\circ} \mathrm{C}\right)$ and the incorporation of an oxygen partial pressure (60 bar) on the transition of BT from cubic to a pseudo-tetragonal phase. The results demonstrated that the oxygen partial pressure plays a crucial role in the BT nanoparticle formation under hydrothermal conditions, advantaging the increase of the ferroelectric exchange interactions, which are mediated by the oxygen ions, influencing of this mode, in the ferroelectric properties of BT. Using the same method, Fuentes et al. also synthesized $\operatorname{SrTi}_{(1-\mathrm{x})} \mathrm{O}_{3}: \mathrm{Fe}_{x}$ powders with $x=0,1,3$ and $5 \mathrm{~mol} \%$ $\mathrm{Fe}, \mathrm{Ba}_{1-\mathrm{x}} \mathrm{Sr}_{x} \mathrm{TiO}_{3}(x=0-1)$ and $\mathrm{BaTiO}_{3}-\mathrm{ZnO}:$ Eu heterostructures [46-48]. The results indicated increasing substitutional doping of $\mathrm{Fe}$ in $\mathrm{SrTiO}_{3}$ and that $\mathrm{Sr}$ ions were in the 2+ oxidation state in the perovskite structure, $\mathrm{Fe}$ participate as a mixture of $\mathrm{Fe}^{3+}$ and $\mathrm{Fe}^{4+}$ oxidation states, increasing the formation of oxygen vacancies as the Fe content increased in the sample. On the other hand, the reactant type used: $\mathrm{BaCl}_{2}$ and $\mathrm{SrCl}_{2}$ or $\mathrm{Ba}(\mathrm{OH})_{2}$ and $\mathrm{Sr}(\mathrm{OH})_{2}$ salts, directly influences the chemical and structural properties of $\mathrm{Ba}_{1-x} \mathrm{Sr}_{x} \mathrm{TiO}$ (BST) nanoparticles grown. The presence of $\mathrm{Cl}^{-}$ions resulted in a better Sr incorporation into the network of BST when the Ba:Sr mole ratio used in the starting reactants was less than one and the presence of $\mathrm{OH}^{-}$ions led to BST nanoparticles with less structural defects and oxygen vacancies.

\subsection{Synthesis of $\mathrm{LaMnO}_{3}$ Nanoparticles}

$\mathrm{LaMnO}_{3}(\mathrm{LMO})$ is a perovskite with the general formula $\mathrm{ABO}_{3}$. Each $\mathrm{B}$ atom occupies the vertex of the perovskite lattice and six oxygen atoms surround it to form an octahedron. The A element occupies the center of eight octahedrons. The oxidation state of B cation can be modulated by varying preparation steps during the perovskite synthesis, such as temperature [21], non-stoichiometry of cations A or B [12,14] or substituting $\mathrm{La}^{3+}$ by 
lower oxidation state cations, such as $\mathrm{Ca}^{2+}, \mathrm{Ba}^{2+}$ or $\mathrm{Sr}^{2+}$, or even higher oxidation state cation such as $\mathrm{Ce}^{4+}$. Sol-Gel technique is one of the easiest and most efficient methods to synthesize different $\mathrm{LaMnO}_{3} \mathrm{NPs}$. Several groups have reported the formation of $\mathrm{LaMnO}_{3}$ nanostructures via Sol-Gel method [49-51].

The typical studies focus on the optimization of the synthesis conditions during the Sol-Gel process to improve the oxidation capacity $\left(\mathrm{Mn}^{3+} / \mathrm{Mn}^{4+}\right.$ mixed oxidation state), including complexant agent to metal nitrate ratio, $\mathrm{pH}$ of the gel and calcination protocol to get pure perovskites with no phase segregation and enhanced textural properties. Xue et al. [52] obtained nanocrystalline LMO powders by Sol-Gel combustion method. They reported the effect of citric acid (CA) to metal nitrates $(\mathrm{MN})$ molar ratio of the precursor solution on the structure of gels and the powders. The crystallite size of the as-formed $\mathrm{LMO}$ powders increases with increasing the CA/MN molar ratio from 30 at $100 \mathrm{~nm}$. In a similar study, Miao et al. [53] prepared modified LMO perovskites with porous tubular skeleton structure. They integrated this NPs into a double network hydrogel and dispersed in polyacrylamide (PAM)/polyvinyl alcohol (PVA) matrixes to prepare a flexible supercapacitor. The LMO-PAM/PVA hydrogel electrodes showed a significant improvement in mechanical properties and charge-discharge cycle stability. These encouraging results were attributed to the double network structure of the hydrogel electrodes and the introduction of LMO nanoparticles.

Liu et al. [54] produced LMO of high surface area using CA and EDTA as chelating agents. They found that EDTA-citrate produced smaller NPs than the single citrate acid. The samples exhibited a high specific surface area showing excellent oxygen reduction and evolution reaction catalytic performance.

In another work, Shaterian et al. [55] prepared LMO nanoparticles via Sol-Gel process using stearic acid as complexing reagent. The as-synthesized nanoparticles showed pure perovskite structure which presented a rhombohedral structure with average particle sizes of 20-30 nm. More recently, Onrubia-Calvo et al. [56] prepared a series of Sr-doped $\mathrm{La}_{1-\mathrm{x}} \mathrm{Sr}_{\mathrm{x}} \mathrm{MnO}_{3}$ perovskites $(\mathrm{x}=0.1,0.2,0.3,0.4$ and 0.5$)$ by varying citrate to nitrate molar ratio in the starting solution, $\mathrm{pH}$ and calcination protocol.

Conversely, Chaozhu Shu et al. [57] used a facile nonstoichiometric strategy to introduce A-site cationic vacancies in $\mathrm{LaMnO}_{3}, \mathrm{La}_{0.9} \mathrm{MnO}_{3}, \mathrm{La}_{0.7} \mathrm{MnO}_{3}$, perovskite oxides were synthesized by combining Sol-Gel method and thermal treatment process in air. This procedure provides the advantage of great specific surface area and abundant cationic La vacancies on the surface, $\mathrm{La}_{0.7} \mathrm{MnO}_{3-\delta}\left(\mathrm{L}_{0.7} \mathrm{MO}\right)$ can provide effective active sites for oxygen electrode reactions and a large storage space for $\mathrm{Li}_{2} \mathrm{O}_{2}$ accommodation.

\section{Synthesis of Vanadium Oxides}

Vanadium oxides display a wide range of oxides states ranging from $\mathrm{V}^{2+}$ to $\mathrm{V}^{5+}$, leading to different valence and mix valence states. $\mathrm{V}_{2} \mathrm{O}_{5}$ and their variations $\mathrm{V}_{2} \mathrm{O}_{5} \cdot \mathrm{nH}_{2} \mathrm{O}$ (xerogel), $\mathrm{NH}_{4} \mathrm{VO}_{3}, \mathrm{VO}(\mathrm{OR})_{3}$ and $\mathrm{VOCl}_{3}$ are well-known as intercalation host lattices. Many guest molecules can be reversibly intercalated in the oxide layers under soft chemical reactions [58]. Which, in turn, induces structural changes on the vanadium oxides and different shapes and morphologies can be obtained [59]. Under hydrothermal treatment, novel structures have been reported. These structures feature a mix oxidation state ratio $\left(\mathrm{V}^{3+}\right.$ to $\left.\mathrm{V}^{5+}\right)$, however, the relation between morphology and oxidation state is still under debate.

For the Sol-Gel synthesis an alkoxide is used as precursor which, after hydrolysis and condensation reactions, can lead to different vanadium morphologies. Normally this process can be tuned with hydrothermal treatment varying the reaction times and the temperature. A simple route to obtain xerogel is described as follows [60]:

$$
\mathrm{V}_{2} \mathrm{O}_{5}(\mathrm{~s})+6\left(\mathrm{CH}_{3}\right)_{3} \mathrm{COH}_{(\mathrm{l})} \stackrel{\text { Reflux }}{\rightarrow} 2 \mathrm{VO}\left(\mathrm{OC}\left(\mathrm{CH}_{3}\right)_{3}\right)_{3(1)}+3 \mathrm{H}_{2} \mathrm{O}_{(1)}
$$


By adding water, the hydrolysis reaction takes place

$$
\mathrm{VO}\left(\mathrm{OC}\left(\mathrm{CH}_{3}\right)_{3}\right)_{3(1)}+\mathrm{H}_{2} \mathrm{O}_{(1)} \leftrightarrow \mathrm{VO}(\mathrm{OH})\left(\mathrm{OC}\left(\mathrm{CH}_{3}\right)_{3}\right)_{2(1)}+\left(\mathrm{CH}_{3}\right)_{3} \mathrm{COH}_{(1)}
$$

The condensation reaction immediately runs forming the layered xerogel

$$
\begin{gathered}
\mathrm{VO}\left(\mathrm{OC}\left(\mathrm{CH}_{3}\right)_{3}\right)_{3(\mathrm{l})}+\mathrm{VO}(\mathrm{OH})\left(\mathrm{OC}\left(\mathrm{CH}_{3}\right)_{3}\right)_{2(1)} \leftrightarrow\left(\left(\mathrm{CH}_{3}\right)_{3} \mathrm{CO}\right)_{3} \mathrm{OV}-\mathrm{O}-\mathrm{VO}\left(\mathrm{OC}\left(\mathrm{CH}_{3}\right)_{3}\right)_{2(1)}+\left(\mathrm{CH}_{3}\right)_{3} \mathrm{COH}_{(1)} \\
\mathrm{VO}(\mathrm{OH})\left(\mathrm{OC}\left(\mathrm{CH}_{3}\right)_{3}\right)_{2(1)}+\mathrm{VO}(\mathrm{OH})\left(\mathrm{OC}\left(\mathrm{CH}_{3}\right)_{3}\right)_{2(1)} \leftrightarrow\left(\left(\mathrm{CH}_{3}\right)_{3} \mathrm{CO}\right)_{2} \mathrm{OV}-\mathrm{O}-\mathrm{VO}\left(\mathrm{OC}\left(\mathrm{CH}_{3}\right)_{3}\right)_{2(1)}+\mathrm{H}_{2} \mathrm{O}_{(1)}
\end{gathered}
$$

Xerogel is used to develop many vanadium oxides nanostructures, alkylamines and thiols (usually 1-octadecanethiol) have been successfully intercalated between the layers. Once thiols formed the layered nanocomposite with xerogel, the compound is submitted to hydrothermal treatment at $180{ }^{\circ} \mathrm{C}$ during seven days. This process induces six folds symmetric cogs [61] and the star fruit morphology [62] (see Figure 4).

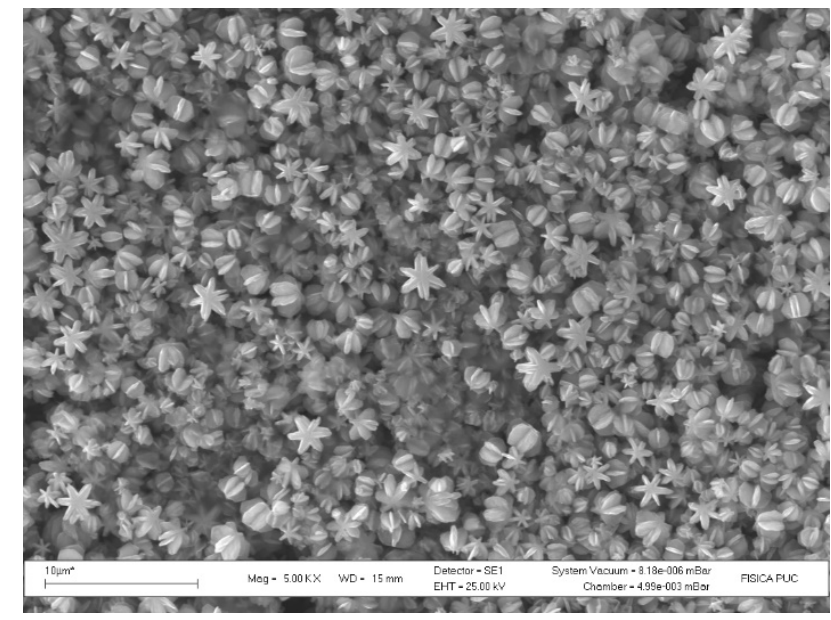

(a)

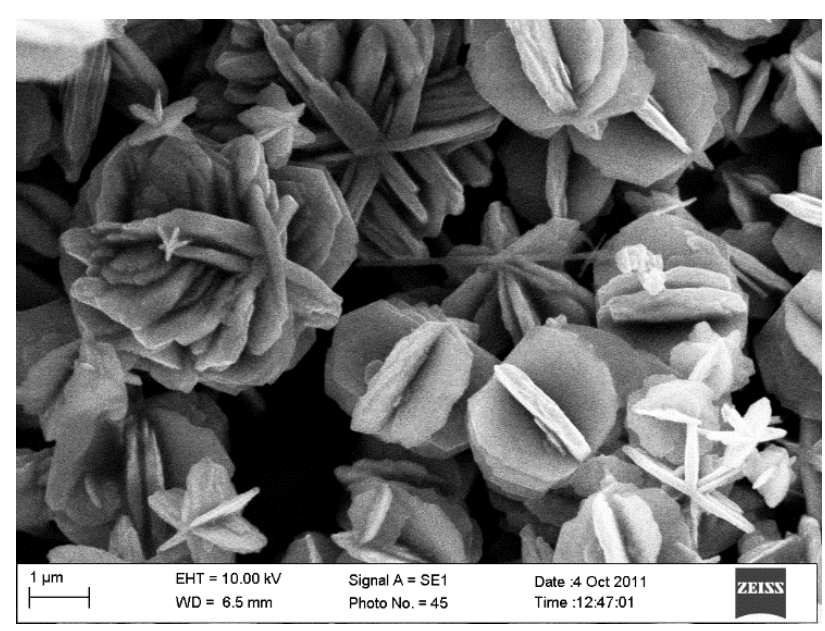

(b)

Figure 4. SEM Micrographs of Vanadium oxides: (a) High yield synthesis of vanadium oxides nanocogs. (b) $\mathrm{V}_{6} \mathrm{O}_{11}$ architecture rotationally six folds layered material.

Other morphologies that can be synthetized via Sol-Gel are nanotubes and nanourchins [63,64]. The first stage of the synthesis starts with the alkoxyde $\left(\mathrm{VO}\left(\mathrm{OCH}\left(\mathrm{CH}_{3}\right)_{2}\right)_{3}\right)$ precursor in presence of alkylamine (e.g., hexadecylamine $\left.\mathrm{CH}_{3}\left(\mathrm{CH}_{2}\right)_{14} \mathrm{CH}_{2} \mathrm{NH}_{2}\right)$ ). The water and ethanol turns into an intercalated alkylamine $-\mathrm{V}_{2} \mathrm{O}_{5}$ layered nanocomposite. Subsequently, the reaction is subjected to hydrothermal treatment for seven days at $180^{\circ} \mathrm{C}$. The composites rolls up originating vanadium oxide nanotubes or nanourchins [65] (high density vanadium oxide nanotubes arrangement spherical clusters) which only differs on the stoichiometry molar proportion (see Figure 5).

Hydrolysis stage:

$$
\mathrm{VO}\left(\mathrm{OCH}\left(\mathrm{CH}_{3}\right)_{2}\right)_{3(1)}+\mathrm{H}_{2} \mathrm{O}_{(1)} \leftrightarrow \mathrm{VO}(\mathrm{OH})\left(\mathrm{OCH}\left(\mathrm{CH}_{3}\right)_{2}\right)_{2(1)}+\left(\mathrm{CH}_{3}\right)_{2} \mathrm{CHOH}_{(\mathrm{ac})}
$$

\section{Condensation stages}

$$
\begin{gathered}
\mathrm{VO}\left(\mathrm{OCH}\left(\mathrm{CH}_{3}\right)_{2}\right)_{3(\mathrm{l})}+\mathrm{VO}(\mathrm{OH})\left(\mathrm{OCH}\left(\mathrm{CH}_{3}\right)_{2}\right)_{2(1)} \leftrightarrow\left(\left(\mathrm{CH}_{3}\right)_{2} \mathrm{HCO}\right)_{2} \mathrm{OV}-\mathrm{O}-\mathrm{VO}\left(\mathrm{OCH}\left(\mathrm{CH}_{3}\right)_{2}\right)_{2(1)}+\left(\mathrm{CH}_{3}\right)_{2} \mathrm{CHOH}_{(\mathrm{ac})} \\
\mathrm{VO}(\mathrm{OH})\left(\mathrm{OCH}\left(\mathrm{CH}_{3}\right)_{2}\right)_{2(1)}+\mathrm{VO}(\mathrm{OH})\left(\mathrm{OCH}\left(\mathrm{CH}_{3}\right)_{2}\right)_{2(1)} \leftrightarrow\left(\left(\mathrm{CH}_{3}\right)_{2} \mathrm{HCO}\right)_{2} \mathrm{OV}-\mathrm{O}-\mathrm{VO}\left(\mathrm{OCH}\left(\mathrm{CH}_{3}\right)_{2}\right)_{2(1)}+\mathrm{H}_{2} \mathrm{O}_{(\mathrm{l})}
\end{gathered}
$$




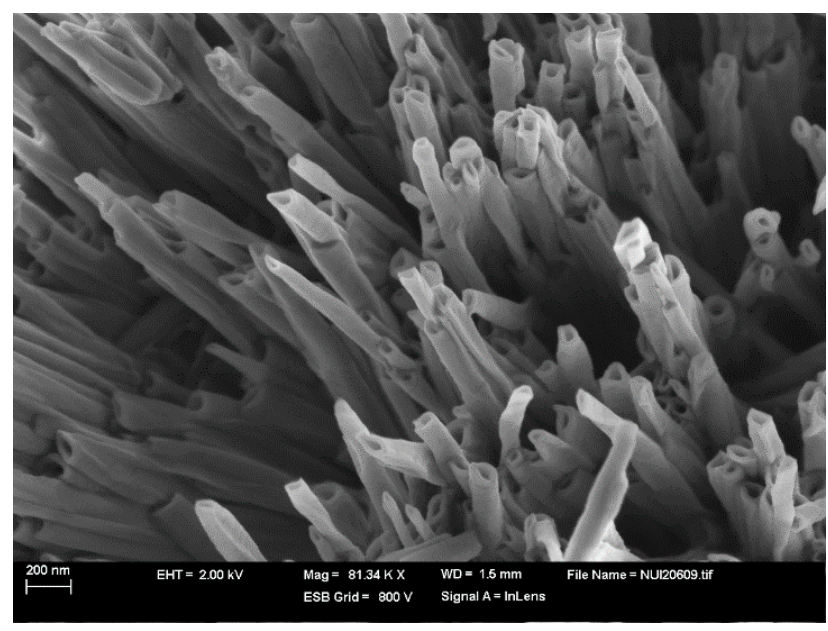

(a)

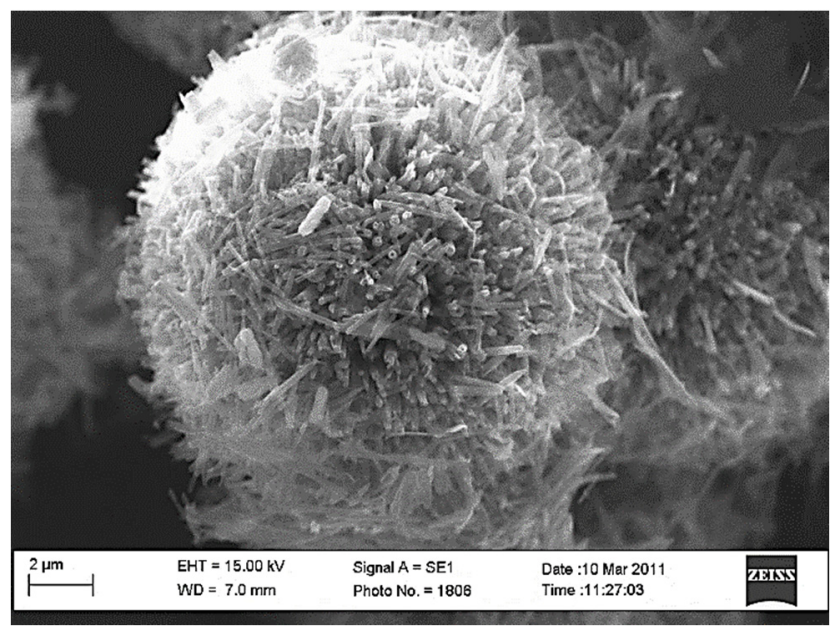

(b)

Figure 5. SEM Micrographs vanadium oxides: (a) nanotubes, (b) center hollowed vanadium oxide nanourchin.

Another interesting microstructure are $\left(\mathrm{enH}_{2} \mathrm{~V}_{7} \mathrm{O}_{16}\right)$ and $\left(\mathrm{NH}_{4}\right)_{2} \mathrm{~V}_{7} \mathrm{O}_{16}$ layeredcompounds $[66,67]$. These compounds are synthesized using $\mathrm{V}_{2} \mathrm{O}_{5}$ precursor with ethylenediamine (en) suspended in a mixture of water-ethanol. Then the mixture is treated with acetic acid or $\mathrm{NH}_{4} \mathrm{VO}_{3}$ with $\mathrm{NaBH}_{4}$ in water. The synthesis is aided with hydrothermal treatment. Another procedure to obtain $\left(\mathrm{NH}_{4}\right)_{2} \mathrm{~V}_{7} \mathrm{O}_{16}$ was performed by Navas et al. [68], they treated the $\mathrm{NH}_{4} \mathrm{VO}_{3}$ precursor with acetic acid in presence of 1-hexadecylamine dissolved in ethanol. Then, the vanadium alkoxyde was obtained by decreasing the $\mathrm{pH}$ of the system. Once water is added, an intercalation compound is formed under the Sol-Gel process. A hydrothermal treatment for at least $24 \mathrm{~h}$ at $180{ }^{\circ} \mathrm{C}$ yields squared layered structures of different sizes (see Figure 6). This morphology can be modified into $\mathrm{VO}_{2}$ crosses by changing the reaction time and working temperature (10 days and $\left.200{ }^{\circ} \mathrm{C}\right)$. The whole process can be described as follows:

$$
\mathrm{NH}_{4} \mathrm{VO}_{3}(\mathrm{ac})+3 \mathrm{CH}_{3} \mathrm{COOH}_{(\mathrm{ac})} \rightarrow \mathrm{VO}\left(\mathrm{OOCCH}_{3}\right)_{3(\mathrm{ac})}+\mathrm{NH}_{4} \mathrm{OH}_{(\mathrm{ac})}+\mathrm{H}_{2} \mathrm{O}_{(\mathrm{l})}
$$

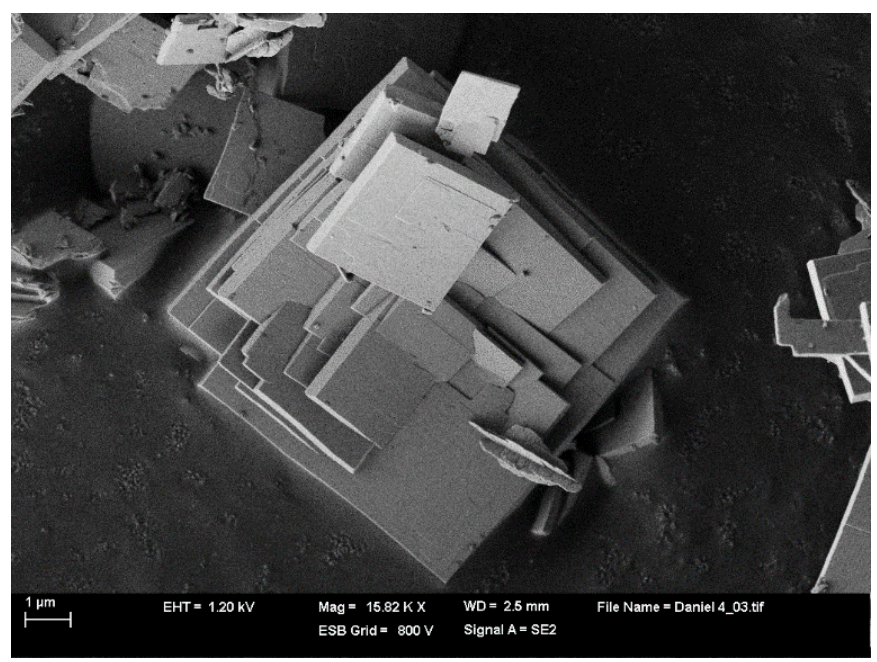

(a)

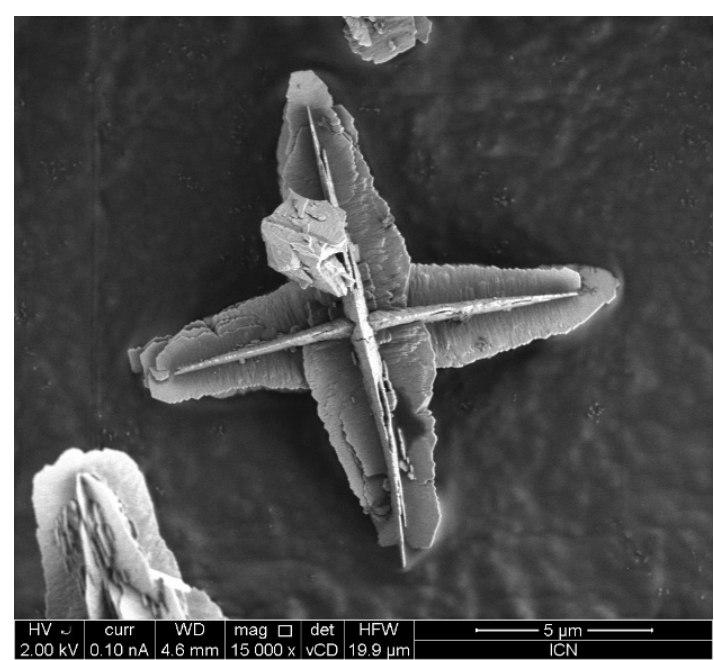

(b)

Figure 6. SEM Micrographs of: (a) $\left(\mathrm{NH}_{4}\right)_{2} \mathrm{~V}_{7} \mathrm{O}_{16}$ microsquares, and (b) Isolated $\mathrm{VO}_{2}$ cross.

Hydrolysis stage

$$
\mathrm{VO}\left(\mathrm{OOCCH}_{3}\right)_{3(\mathrm{ac})}+\mathrm{H}_{2} \mathrm{O}_{(\mathrm{l})} \leftrightarrow \mathrm{VO}(\mathrm{OH})\left(\mathrm{OOCCH}_{3}\right)_{2(\mathrm{ac})}+\mathrm{CH}_{3} \mathrm{COOH}_{(\mathrm{ac})}
$$


Condensation stages

$$
\begin{gathered}
\mathrm{VO}\left(\mathrm{OOCCH}_{3}\right)_{3(\mathrm{ac})}+\mathrm{VO}(\mathrm{OH})\left(\mathrm{OOCCH}_{3}\right)_{2(\mathrm{ac})} \leftrightarrow\left(\mathrm{OOCCH}_{3}\right)_{2} \mathrm{OV}-\mathrm{O}-\mathrm{VO}\left(\mathrm{OOCCH}_{3}\right)_{2(\mathrm{ac})}+\mathrm{CH}_{3} \mathrm{COOH}_{(\mathrm{ac})} \\
\mathrm{VO}(\mathrm{OH})\left(\mathrm{OOCCH}_{3}\right)_{2(\mathrm{ac})}+\mathrm{VO}(\mathrm{OH})\left(\mathrm{OOCCH}_{3}\right)_{2(\mathrm{ac})} \leftrightarrow\left(\mathrm{OOCCH}_{3}\right)_{2} \mathrm{OV}-\mathrm{O}-\mathrm{VO}\left(\mathrm{OOCCH}_{3}\right)_{2}(\mathrm{ac}) \\
+\mathrm{H}_{2} \mathrm{O}_{(\mathrm{l})}
\end{gathered}
$$

\section{Synthesis of Zinc Oxides}

Throughout the years, $\mathrm{ZnO}$ nanostructures and nanoparticles (ZnO NPs) have been a subject of research for promising applications in many technological, chemical and biological fields [69-75]. The different chemical routes to produce $\mathrm{ZnO}$ have been incorporated to produce 1D (nanotubes, nanoparticles, nanowires, nanorods) [3,76-80], 2D (nanosheets, nanoplates and nanopellets) and many 3D self-assemble with novel morphologies flowers, urchins, and dandelions [75,81-83]. Even though, these fascinating nanostructures can offer novel properties to $\mathrm{ZnO}$, some defects are often found in the shape, size distribution and homogeneity. In general, these defects have a correlation with the chemical synthetic approach, starting from the $\mathrm{Zn}^{2+}$ salts precursors, $\mathrm{pH}$, solvents, reaction time and temperature, additives like surfactants and other organic molecules, etc. [84-86]. One of the main challenges with these synthetic procedures is to control the size distributions, which can be vary from a few nanometers to micrometers. In terms of synthesis, the precursor $\mathrm{Zn}\left(\mathrm{CH}_{3} \mathrm{COO}\right)_{2} \cdot 2 \mathrm{H}_{2} \mathrm{O}$ has been widely used because it provides a moderate hydrolysis step, which can be controlled using organic molecules (e.g., surfactants or glycols), nitrogenated amines (used as the precipitating agent) or ethanol. This process originates ZnO NPs with a narrow size distribution ranging from 14 to $70 \mathrm{~nm}$ [87-89].

A short and simple Sol-Gel route to obtain $\mathrm{ZnO}$ nanostructures was reported by YungKuan Tseng et al. [90] The authors described a hydrolysis and condensation processes from zinc acetate dihydrate with different types of glycols: ethylene glycol (EG), glycerol (GLY) and diethylene glycol (DEG) performed under reflux for one hour and increasing the temperature up to $160^{\circ} \mathrm{C}$ (heating rate used $1^{\circ} \mathrm{C} /$ minute). The final products were treated under two different heating processes, dripped onto silicon wafers at $160^{\circ} \mathrm{C}$ and calcined at $500{ }^{\circ} \mathrm{C}$. Under these conditions they generated three different morphologies with each solvent: fibers, flakes and spheres. The fabrication steps are given by:

Step 1

$$
\mathrm{Zn}\left(\mathrm{CH}_{3} \mathrm{COO}\right)_{2}+\mathrm{HO}-\mathrm{CH}_{2} \mathrm{CH}_{2}-\mathrm{OH} \stackrel{\text { Reflux }}{\rightarrow} \mathrm{Zn}^{2+} .{ }^{-} \mathrm{OCH}_{2} \mathrm{CH}_{2} \mathrm{O}^{-}+2 \mathrm{CH}_{3} \mathrm{COO}^{-}+2 \mathrm{H}^{+}
$$

Step 2

$$
\begin{gathered}
\frac{3}{2} \mathrm{Zn}\left(\mathrm{CH}_{3} \mathrm{COO}\right)_{2}+\mathrm{HO}-\mathrm{CH}_{2} \mathrm{CHOHCH}_{2}-\mathrm{OH} \stackrel{\text { Reflux }}{\rightarrow} \frac{3}{2} \mathrm{Zn}^{2+} .{ }^{-} \mathrm{OCH}_{2} \mathrm{CHOHCH}_{2} \mathrm{O}^{-}+3 \mathrm{CH}_{3} \mathrm{COO}^{-}+3 \mathrm{H}^{+} \\
\mathrm{Zn}\left(\mathrm{CH}_{3} \mathrm{COO}\right)_{2}+\mathrm{HO}-\mathrm{CH}_{2} \mathrm{CH}_{2} \mathrm{OCH}_{2} \mathrm{CH}_{2}-\mathrm{OH} \stackrel{\text { Reflux }}{\rightarrow} \mathrm{Zn}^{2+} .{ }^{-} \mathrm{OCH}_{2} \mathrm{CH}_{2} \mathrm{OCH}_{2} \mathrm{CH}_{2} \mathrm{O}^{-}+2 \mathrm{CH}_{3} \mathrm{COO}^{-}+2 \mathrm{H}^{+}
\end{gathered}
$$

The fibers are formed by the assembly of several unit structures of $\mathrm{Zn}^{2+}$ and the solvents (EG, GLY and DEG). For EG-based structures, $\mathrm{Zn}^{2+}-{ }^{-} \mathrm{OCH}_{2} \mathrm{CH}_{3} \mathrm{O}^{-}$terminal oxygen ions are formed, depending on temperature used at the final stage different shapes can be obtained. Samples dried at $160^{\circ} \mathrm{C}$ reveal smooth surface, whereas the samples annealed at $500{ }^{\circ} \mathrm{C}$ in air results into small $\mathrm{ZnO}$ particles (see Figure 7a1,a2). 


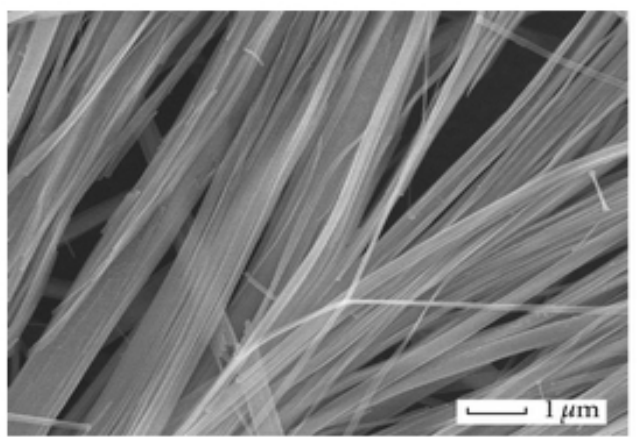

(a1)

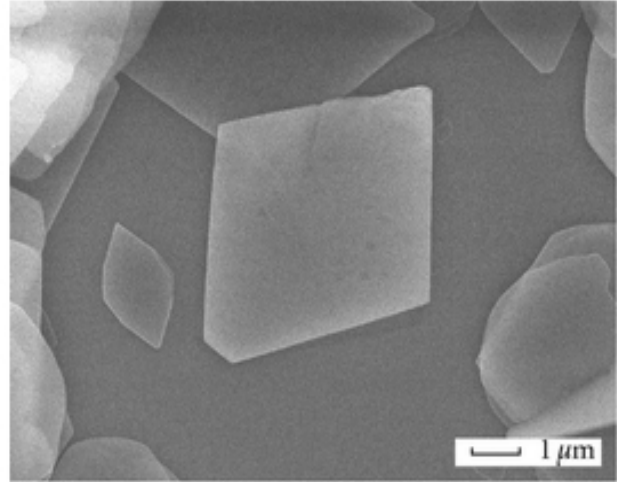

(bl)

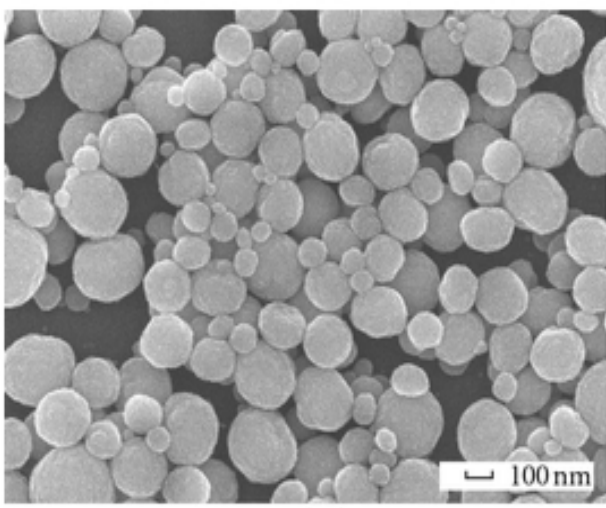

(c1)

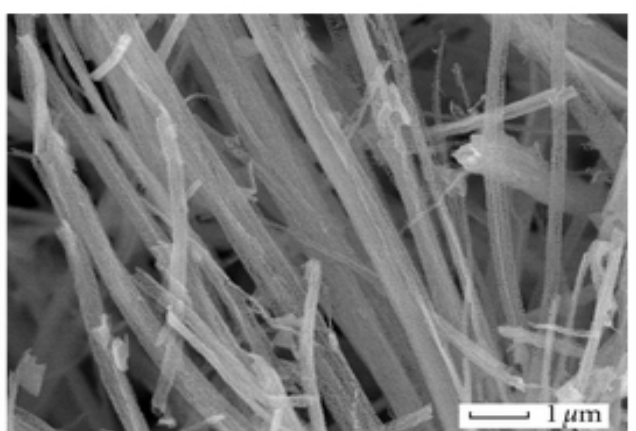

(a2)

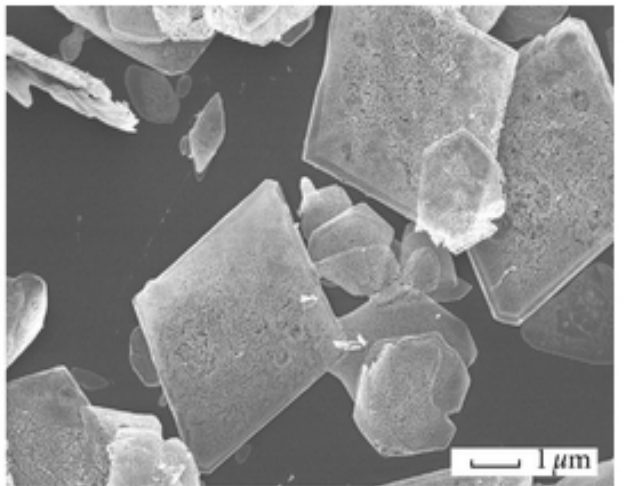

(b2)

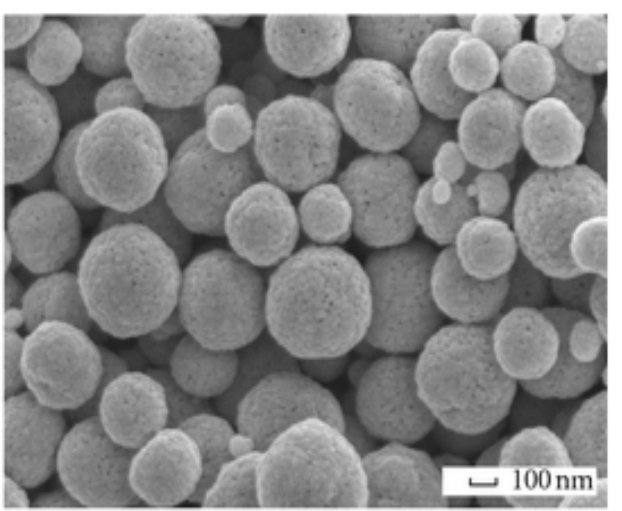

(c2)

Figure 7. SEM images of different $\mathrm{ZnO}$ nanstructures obtained with different glycol solvents and heated at $160{ }^{\circ} \mathrm{C}(1)$ and calcined at $500{ }^{\circ} \mathrm{C}(2)$ : (a1,a2) ethylene glycol, (b1,b2), glycerol and (c1,c2) diethylene glycol solvents. Adapted from [90].

Another popular synthesis is the precipitation method using a titration to ensure a controlled Sol-Gel reaction. Md Jahidul Haque et al. [91] reported a synthesis route using $\mathrm{Zn}\left(\mathrm{CH}_{3} \mathrm{COO}\right)_{2} \cdot 2 \mathrm{H}_{2} \mathrm{O}$ as precursor mixed with $\mathrm{NaOH}$ dissolution at $35^{\circ} \mathrm{C}$. Once mixtures turn homogeneous, methanol was added dropwise under vigorous stirring for $90 \mathrm{~min}$ until a white gel was formed. The gel was dried overnight at $80{ }^{\circ} \mathrm{C}$ and calcinated at $250{ }^{\circ} \mathrm{C}$ during four hours. The reaction is given by:

$$
\mathrm{Zn}\left(\mathrm{CH}_{3} \mathrm{COO}\right)_{2} \times 2 \mathrm{H}_{2} \mathrm{O}_{(\mathrm{aq})}+2 \mathrm{NaOH}_{(\mathrm{aq})} \stackrel{\mathrm{CH}_{3} \mathrm{OH}}{\rightarrow} \mathrm{ZnO}_{(\mathrm{s})}+2 \mathrm{CH}_{3} \mathrm{COONa}_{(\mathrm{aq})}+\mathrm{H}_{2} \mathrm{O}_{(\mathrm{l})}
$$

This synthesis was performed using a strong base which has the ability to ionize completely in water. Shokuhfar et al. [92], on the other hand, performed the Sol-Gel processes using a weak base which usually developed a partial ionization $(\% \mathrm{I}<5 \%)$. They used triethanolamine $\left(\mathrm{N}\left(\mathrm{CH}_{3} \mathrm{CH}_{2} \mathrm{OH}\right)_{3}, \mathrm{TEA}\right)$ as surfactant, with methanolic solutions of 
$\mathrm{Zn}\left(\mathrm{CH}_{3} \mathrm{COO}\right)_{2} \cdot 2 \mathrm{H}_{2} \mathrm{O}$ at different ratios. The resultant solution was kept at $50{ }^{\circ} \mathrm{C}$ all night allowing the completion of hydrolysis and condensation reactions. The final product was calcinated at $500{ }^{\circ} \mathrm{C}$ and $\mathrm{ZnO}$ Nps were obtained. The increase of the surfactant concentration led to a smaller particle size with narrow size distribution and enhanced homogeneity.

Azimul Haque and Mahalakshmi [93] performed the precipitation processes avoiding the Sol-Gel step. The authors used the same weak base with a partial ionization $(<5 \%)$, TEA as a complexating agent (Lewis base role, electron pair donor) in combination with a strong base $\mathrm{NaOH}$ and $\mathrm{Zn}\left(\mathrm{CH}_{3} \mathrm{COO}\right)_{2} \cdot 2 \mathrm{H}_{2} \mathrm{O}$ as $\mathrm{Zn}^{2+}$ source. $\mathrm{Zn}^{2+}$ and TEA reagents were mixed and stirred at $80{ }^{\circ} \mathrm{C}$ bath. $\mathrm{NaOH}$ was added drop by drop until $\mathrm{pH}$ reaches 11 . A white precipitate was washed up several times and dried at $60^{\circ} \mathrm{C}$. The TEA was used to obtain wurtzite structure. The precipitation was tuned by changing the temperature, $\mathrm{pH}$ and synthetic procedures.

For this method two mechanisms have been proposed:

Mechanism 1

$$
\begin{aligned}
& \mathrm{Zn}\left(\mathrm{CH}_{3} \mathrm{COO}\right)_{2} \times 2 \mathrm{H}_{2} \mathrm{O}_{(\mathrm{aq})}+2 \mathrm{TEA}_{(\mathrm{aq})} \rightarrow \mathrm{Zn}[\mathrm{TEA}]_{(\mathrm{aq})}+2 \mathrm{CH}_{3} \mathrm{COO}_{(\mathrm{ac})}^{-} \\
& \mathrm{Zn}[\mathrm{TEA}]_{(\mathrm{aq})} \rightarrow \mathrm{Zn}_{(\mathrm{ac})}^{2+}+\mathrm{TEA}_{(\mathrm{aq})} \\
& 2 \mathrm{NaOH}_{(\mathrm{s})} \stackrel{\mathrm{H}_{2} \mathrm{O}}{\rightarrow} 2 \mathrm{Na}_{(\mathrm{ac})}^{+}+2 \mathrm{OH}_{(\mathrm{ac})}^{-} \\
& \mathrm{Zn}_{(\mathrm{ac})}^{2+}+2 \mathrm{OH}_{(\mathrm{ac})}^{\rightarrow} \mathrm{Zn}(\mathrm{OH})_{2}(\mathrm{~s}) \\
& \mathrm{Zn}(\mathrm{OH})_{2(\mathrm{~s})} \stackrel{\stackrel{\leftrightarrow}{\rightarrow}}{\mathrm{ZnO}_{(\mathrm{s})}}+\mathrm{H}_{2} \mathrm{O}_{(\mathrm{g})}
\end{aligned}
$$

Mechanism 2

$$
\begin{gathered}
\mathrm{Zn}\left(\mathrm{CH}_{3} \mathrm{COO}\right)_{2} \times 2 \mathrm{H}_{2} \mathrm{O}_{(\mathrm{aq})}+2 \mathrm{TEA}_{(\mathrm{aq})} \rightarrow \mathrm{Zn}[\mathrm{TEA}]_{(\mathrm{aq})}+2 \mathrm{CH}_{3} \mathrm{COO}_{(\mathrm{ac})}^{-} \\
\mathrm{Zn}[\mathrm{TEA}]_{(\mathrm{aq})} \rightarrow \mathrm{Zn}_{(\mathrm{ac})}^{2+}+\mathrm{TEA}_{(\mathrm{aq})} \\
2 \mathrm{NaOH}_{(\mathrm{s})} \stackrel{\mathrm{H}_{2} \mathrm{O}}{\rightarrow} 2 \mathrm{Na}_{(\mathrm{ac})}^{+}+2 \mathrm{OH}_{(\mathrm{ac})}^{-} \\
\mathrm{Zn}_{(\mathrm{ac})}^{2+}+2 \mathrm{OH}_{(\mathrm{ac})}^{-} \rightarrow \mathrm{Zn}(\mathrm{OH})_{2}(\mathrm{~s}) \\
\mathrm{Zn}(\mathrm{OH})_{2(\mathrm{~s})}+2 \mathrm{OH}_{(\mathrm{ac})}^{-} \leftrightarrow \mathrm{Zn}(\mathrm{OH})_{4}^{2-}(\mathrm{aq}) \\
\mathrm{Zn}(\mathrm{OH})_{4(\mathrm{aq})}^{2-} \rightarrow \mathrm{ZnO}_{(\mathrm{s})}+\mathrm{H}_{2} \mathrm{O}_{(\mathrm{g})}+2 \mathrm{OH}_{(\mathrm{ac})}^{-}
\end{gathered}
$$

Even though both mechanisms are quite similar, the addition of TEA plays an outstanding role in the morphology of $\mathrm{ZnO} N P s$ enhancing the conversion from $\mathrm{Zn}(\mathrm{OH})_{2}$ to $\mathrm{ZnO}$.

\section{Bioorganic Material in Sol-Gel Preparation}

The Pechini synthesis ensures that metal ions are combined and stabilized homogeneously within a covalent matrix or 'gel' by synthesizing a polymer in situ. Consequently, it seems natural that new variants consider the direct synthesis of Sol-Gel precursors from natural or synthetic polymers. The polymers create well-defined structures in solution, and metal ions have strong interactions with them. The ability of some polymers to create ordered superstructures can be used to control the morphology of the desired material.

Authors such as Liu et al. [94], Shao et al. [95] and Yong-Jin Han et al. [96] have worked with organic compounds and zinc or vanadium oxide $[97,98]$ obtain new functional materials such as supercapacitors [99,100], taking advantage of the benefits offered by organic materials in relation to the natural and structured arrangement provided by the different natural sources from which they are obtained.

Yoseph Bar-Cohen coined the statement that "... through evolution, nature has 'experimented' with various solutions to its challenges and has improved the successful ones" [101]. Materials as versatile as activated carbon [102-104], porous carbon [105], graphene $[106,107]$ and carbon nanotubes (CNT) [108-110] have been considered as a prospective type of electrode materials for supercapacitors due to their economic acquisition, high surface area, excellent electrical conductivity and outstanding electrochemical stability $[111,112]$. Each of these materials, however, has drawbacks. Commercial activated 
carbon, for example, has a poor specific capacitance due to its small surface area [113]. On the other hand, CNTs and graphene have a large specific surface area and excellent electrical conductivity, but their manufacturing process is complex and of high economic cost [114]. Furthermore, graphene spontaneously agglomerates and stacks during the production process, limiting its synthesis and large-scale application $[115,116]$.

Therefore, most studies have focused on obtaining porous carbon materials due to their versatility at the time of fabrication and the physicochemical advantages over other types of carbon-based materials. Authors such as Hao et al. obtained hierarchical porous carbon (HPC) aerogel from sugarcane waste products containing mainly cellulose derivatives, bagasse. The porous material was obtained by carbonization of the freeze-dried bagasse aerogel [117] (see Figure 8). The authors' preparation method, by Sol-Gel reaction, results in carbon aerogels with hierarchical macro-, meso- and microporous structures and possessing a high specific surface area $1892.4 \mathrm{~m}^{2} \mathrm{~g}^{-1}$, whose specific capacity was $142 \mathrm{~F} \mathrm{~g}^{-1}$ at $0.5 \mathrm{~A} \mathrm{~g}^{-1}$.

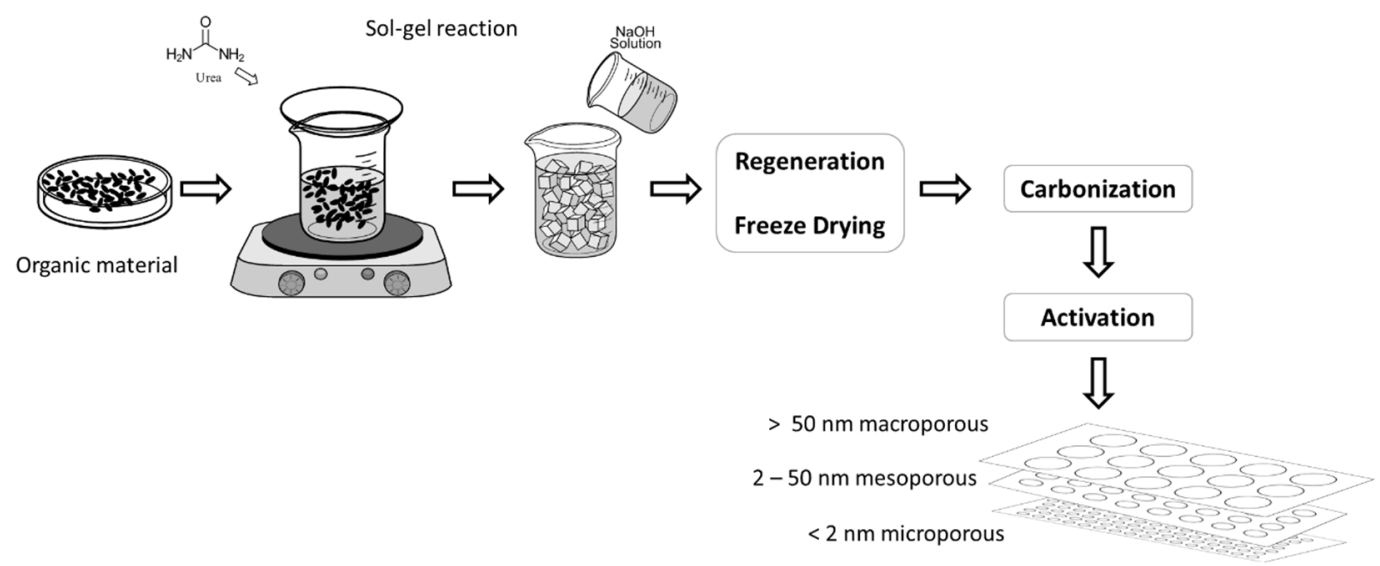

Figure 8. Schematic representation of the fabrication of highly porous bagasse-derived carbon aerogels.

A lot of effort has gone towards designing porous carbon spheres (PCSs) using hydrothermal carbonization [118,119]. Liu et al., for example, used Pluronic F127 as a soft template to generate carbon spheres with organized mesopores and a large surface area $\left(1100 \mathrm{~m}^{2} \mathrm{~g}^{-1}\right)$ during hydrothermal treatment of D-fructose. In a three-electrode configuration, the produced spheres had a high capacitance of $350 \mathrm{~F} \mathrm{~g}^{-1}$ at $1.0 \mathrm{~A} \mathrm{~g}^{-1}$, and a capacitance of $190 \mathrm{~F} \mathrm{~g}^{-1}$ at $2.0 \mathrm{~A} \mathrm{~g}^{-1}$ in a two-electrode configuration [120]. A year later, Wang's group used hydrothermal treatment of glucose and sodium molybdate $\left(\mathrm{Na}_{2} \mathrm{MoO}_{4}\right.$ as a porogen agent to create porous carbon spheres) to create PCSs with a specific capacitance of $260 \mathrm{~F} \mathrm{~g}^{-1}$ outstanding high-speed performance, and strong long-term cycle stability. Alginic acid is carbonized hydrothermally and then activated with $\mathrm{KOH}$ [121]. A brief summary of porous carbon spheres is shown in Figure 9.

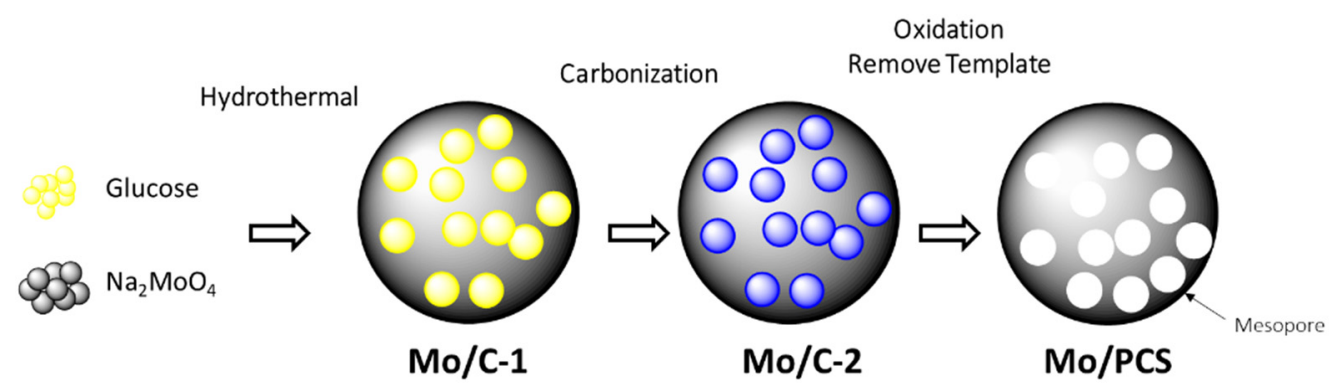

Figure 9. Schematic representation of the fabrication of the porous carbon spheres (PCS). 
Hydrothermal carbonization is a strong, cost-effective, and ecologically acceptable method for converting organic molecules into usable carbon materials. Under mild hydrothermal conditions, a variety of organic compounds such as glucose, sucrose, starch, fructose, alginic acid, among others, can be transformed into carbonaceous spheres [122].

Pan et al. obtained a porous carbon from asphalt, whose properties highlight its high specific capacity of $277 \mathrm{~F} \mathrm{~g}^{-1}$ at a current density of $0.05 \mathrm{~A} \mathrm{~g}^{-1}$. According to the authors, the ultrathin and porous structure reduces resistance by minimizing the diffusion distance of electrolyte ions and aids the plentiful porosity channels as active locations for ion transport and storage [123].

These precedents utilized organic wastes to make porous carbon with good capacitance performance, opening a novel way to transform organic wastes into supercapacitor material and lowering carbon material costs. The specific capacitance of these carbon materials, on the other hand, has yet to increase their scalability. Therefore, it is important to prepare carbon materials with high specific capacity from low-cost biomass feedstock.

These precedents utilized organic wastes to make porous carbon with good capacitance performance, opening a novel way to transform organic wastes into supercapacitor material and lowering carbon material costs. The specific capacitance of these carbon materials, on the other hand, has yet to increase their scalability. Therefore, it is important to prepare carbon materials with high specific capacity from low-cost biomass feedstocks.

In this sense, Kong et al. employed maize starch as a carbon precursor, which they synthesized by dissolving corn starch in $\mathrm{KOH}$ solution and fabricating a starch-based gel after the water was removed. Finally, 3D-reticular porous carbon (3D-RPC) was created by carbonizing a starch gel and activating $\mathrm{KOH}$ in situ (a process like those described by Hao et al.). The advantages of 3D-RPC include a wide surface area, high porosity and an optimum pore size distribution. The macropores formed with this new material (3DRPC) are primarily from the intermediate space between the three-dimensional starch gel networks, whereas the $\mathrm{KOH}$ activation process produced mesopores and micropores. The material's porosity displayed exceptional supercapacitive performance with a $372 \mathrm{~F} \mathrm{~g}^{-1}$ specific capacitance $\left(0.5 \mathrm{~A} \mathrm{~g}^{-1}\right)$. The electrochemical performance of 3D-RPC outperforms that of most previously characterized carbon materials, opening a new path for large-scale production of a low-cost, high-purity porous carbon for supercapacitors [124].

\section{Conclusions}

Sol-Gel method offers a unique synthesis route to produce novel and tailor-made nanomaterials with full control of morphology, size, composition, crystallinity, porosity enhanced by combustion or hydrothermal/solvothermal treatment. Nevertheless, some precautions must be taken in order to obtain the best results. The nanoparticle composition must be analyzed before running the synthesis $(\mathrm{pH}$, working temperature, reaction time, metal cation precursors mixtures). The morphology and size must be also taken into account, e.g., organic surfactants or molecules are required throughout the process. The velocity of both hydrolysis and condensations reactions should be investigated extensively, this is the key stage that leads into the final product and also confers the distinctive feature in every synthesis.

Sol-Gel also offers the possibility to produce in situ doped nanomaterial and mixed lattices. However, a precise control of doping requires full-knowledge of the different equilibriums that take place during hydrolysis and condensation reactions. When doping cation precursors are added, soft chemistry must also be used to avoid fast alterations from the final product.

The size distribution and aspect ratio might be another challenging task to improve. Although the use of organic template molecules as structure directors in many syntheses generates great results, most of the time, secondary phases are originated that affect the performance in different applications.

Sol-Gel processes in the future could be assisted with photocatalysts during synthesis. This could induce the formation of desirable doping processes or could reduce the forma- 
tion of secondary phases. The use of biomaterials in the synthesis of Sol-Gel, especially organic waste, offers a novel low-cost and ecological platform for the manufacture of functional materials.

Author Contributions: Conceptualization, E.C.-A. and S.F.; resources S.F.; writing-original draft preparation, D.N., S.F., A.C.-A. and E.C.-A.; writing-review and editing, D.N. and E.C.-A.; supervision, S.F. and E.C.-A.; funding acquisition, S.F. All authors have read and agreed to the published version of the manuscript.

Funding: This work has been partially financed by P. Fondecyt 1190721 and Basal Financing Program CONICYT, AFB180001 (CEDENNA). ICN2 acknowledges support from Severo Ochoa program, the Spanish Research Agency (AEI, Grant SEV-2017-0706), and the CERCA Programme/Generalitat de Catalunya.

Institutional Review Board Statement: Not applicable.

Informed Consent Statement: Not applicable.

Data Availability Statement: Not applicable.

Conflicts of Interest: The authors declare no conflict of interest.

\section{References}

1. Danks, A.E.; Hall, S.R.; Schnepp, Z. The evolution of 'sol-gel' chemistry as a technique for materials synthesis. Mater. Horizons 2016, 3, 91-112. [CrossRef]

2. Ye, C.-Q. Sol-Gel Processes of Functional Powders and Films. In Chemical Reactions in Inorganic Chemistry; IntechOpen: London, UK, 2018.

3. Purcar, V.; Şomoghi, R.; Niţu, S.G.; Nicolae, C.-A.; Alexandrescu, E.; Gîfu, I.C.; Gabor, A.R.; Stroescu, H.; Ianchiş, R.; Căprărescu, S.; et al. The Effect of Different Coupling Agents on Nano-ZnO Materials Obtained via the Sol-Gel Process. Nanomaterials 2017, 7, 439. [CrossRef] [PubMed]

4. Fu, M.; Li, Y.; Wu, S.; Lu, P.; Liu, J.; Dong, F. Sol-gel preparation and enhanced photocatalytic performance of Cu-doped ZnO nanoparticles. Appl. Surf. Sci. 2011, 258, 1587-1591. [CrossRef]

5. Purcar, V.; Rădițoiu, V.; Dumitru, A.; Nicolae, C.-A.; Frone, A.N.; Anastasescu, M.; Rădiţoiu, A.; Raduly, M.F.; Gabor, R.A.; Căprărescu, S. Antireflective coating based on $\mathrm{TiO}_{2}$ nanoparticles modified with coupling agents via acid-catalyzed sol-gel method. Appl. Surf. Sci. 2019, 487, 819-824. [CrossRef]

6. Spataru, C.I.; Purcar, V.; Ghiurea, M.; Radovici, C.; Stanga, G.; Donescu, D. Effects of the nanoassociation of hexadecyltrimethoxysilane precursors on the sol-gel process. J. Sol-Gel Sci. Technol. 2013, 65, 344-352. [CrossRef]

7. Znaidi, L. Sol-gel-deposited ZnO thin films: A review. Mater. Sci. Eng. B 2010, 174, 18-30. [CrossRef]

8. Ebelmen, M. Sur les combinations des acides borique et silicique avec les élhers. Ann. Chim. Phys. 1846, 16, 129.

9. Graham, T. XXXV.-On the properties of silicic acid and other analogous colloidal substances. J. Chem. Soc. 1864, 17, 318-327. [CrossRef]

10. Ostwald, W. Studien über die Bildung und Umwandlung fester Körper. Z. Phys. Chem. 1897, 22U, 289-330. [CrossRef]

11. Rayleigh, L. LXXVIII. Periodic precipitates. Lond. Edinb. Dublin Philos. Mag. J. Sci. 1919, 38, 738-740. [CrossRef]

12. Liesegang, R.E. Ueber einige Eigenschaften von Gallerten. Z. Chem. Ind. Kolloide 1896, 11, 212; Reprint: Liesegang, R.E. Ueber einige Eigenschaften von Gallerten. Z. Chem. Ind. Kolloide 1907, 1, 212. [CrossRef]

13. Roy, R.; Osborn, E.F. The system $\mathrm{Al}_{2} \mathrm{O}_{3}-\mathrm{SiO}_{2}-\mathrm{H}_{2}$ O. Am. Mineral. 1954, 39, 853-885.

14. Roy, R. Ceramics by the Solution-Sol-Gel Route. Science 1987, 238, 1664-1669. [CrossRef] [PubMed]

15. Dislich, H. New Routes to Multicomponent Oxide Glasses. Angew. Chem. Int. Ed. 1971, 10, 363-370. [CrossRef]

16. Sakka, S. History of the Sol-Gel Chemistry and Technology. In Handbook of Sol-Gel Science and Technology; Springer: Singapore, 2016; pp. 1-27.

17. Web of Science. Available online: https:/ / www.webofscience.com (accessed on 1 December 2021).

18. Parashar, M.; Shukla, V.K.; Singh, R. Metal oxides nanoparticles via sol-gel method: A review on synthesis, characterization and applications. J. Mater. Sci. Mater. Electron. 2020, 31, 3729-3749. [CrossRef]

19. Issa, A.A.; El-Azazy, M.; Luyt, A.S. Kinetics of alkoxysilanes hydrolysis: An empirical approach. Sci. Rep. 2019, 9, 17624. [CrossRef]

20. Athayde, D.; Souza, D.F.; Silva, A.; Vasconcelos, D.; Nunes, E.H.; da Costa, J.C.D.; Vasconcelos, W. Review of perovskite ceramic synthesis and membrane preparation methods. Ceram. Int. 2016, 42, 6555-6571. [CrossRef]

21. Pechini, M.P. Patent: Method of Preparing Lead and Alkaline Earth Titanates and Niobates and Coating Method Using the Same to Form a Capacitor. Available online: https:/ / patents.google.com/patent/US3330697A/en (accessed on 3 November 2021).

22. Kurajica, S. A Brief Review on the Use of Chelation Agents in Sol-gel Synthesis with Emphasis on $\beta$-Diketones and $\beta$-Ketoesters. Chem. Biochem. Eng. Q. 2019, 33, 295-301. [CrossRef] 
23. Shlapa, Y.; Solopan, S.; Belous, A. Nanoparticles of La1-Sr $\mathrm{MnO}_{3}(0.23 \leq \mathrm{x} \leq 0.25)$ manganite: Features of synthesis and crystallochemical properties. J. Magn. Magn. Mater. 2020, 510, 166902. [CrossRef]

24. Wang, G.; Jia, G.; Wang, J.; Kong, H.; Lu, Y.; Zhang, C. Novel rare earth activator ions-doped perovskite-type $\mathrm{La}_{4} \mathrm{Ti}_{3} \mathrm{O}_{12}$ phosphors: Facile synthesis, structure, multicolor emissions, and potential applications. J. Alloys Compd. 2021, 877, 160217. [CrossRef]

25. Garcia, A.; Bispo, A., Jr.; Lima, S.; Pires, A. Effects of the Pechini's modified synthetic route on structural and photophysical properties of $\mathrm{Eu}^{3+}$ or $\mathrm{Tb}^{3+}$-doped $\mathrm{LaAlO}_{3}$. Mater. Res. Bull. 2021, 143, 111462. [CrossRef]

26. Osman, N.; Samat, A.A.; Mat, A.N.C.; Malek, N.I.A.; Andas, J. Chelating agent size effect on thermal decomposition, phase formation and morphology characteristics of $\mathrm{Y}^{3+}$ doped $\mathrm{Ba}(\mathrm{Ce}, \mathrm{Zr}) \mathrm{O}_{3}$ ceramics powder prepared by a sol-gel process. Ceram. Int. 2021, 48, 2289-2297. [CrossRef]

27. Tewatia, K.; Sharma, A.; Sharma, M.; Kumar, A. Factors affecting morphological and electrical properties of Barium Titanate: A brief review. Mater. Today Proc. 2021, 44, 4548-4556. [CrossRef]

28. Santander-Syro, A.F.; Copie, O.; Kondo, T.; Fortuna, F.; Pailhès, S.; Weht, R.; Qiu, X.G.; Bertran, F.; Nicolaou, A.; Taleb-Ibrahimi, A.; et al. Two-dimensional electron gas with universal subbands at the surface of SrTiO 3 . Nat. Cell Biol. 2011, 469, 189-193. [CrossRef]

29. Pai, Y.-Y.; Tylan-Tyler, A.; Irvin, P.; Levy, J. Physics of $\mathrm{SrTiO}_{3}$-based heterostructures and nanostructures: A review. Rep. Prog. Phys. 2017, 81, 036503. [CrossRef]

30. Szafraniak, B.; Fuśnik, Ł.; Xu, J.; Gao, F.; Brudnik, A.; Rydosz, A. Semiconducting Metal Oxides: $\mathrm{SrTiO}_{3}, \mathrm{BaTiO}_{3}$ and BaSrTiO 3 in Gas-Sensing Applications: A Review. Coatings 2021, 11, 185. [CrossRef]

31. Shi, X.; Wu, H.; Liu, Q.; Zhou, W.; Lu, S.; Shao, Z.; Dargusch, M.; Chen, Z.-G. SrTiO 3 -based thermoelectrics: Progress and challenges. Nano Energy 2020, 78, 105195. [CrossRef]

32. Ji, X.; Zhu, Y.; Lian, X.; Fan, B.; Liu, X.; Xiao, P.; Zhang, Y. Hydroxylation mechanism of phase regulation of nanocrystal BaTiO 3 synthesized by a hydrothermal method. Ceram. Int. 2021, 48, 2281-2288. [CrossRef]

33. Kholodkova, A.; Danchevskaya, M.; Ivakin, Y.; Smirnov, A.; Ponomarev, S.; Fionov, A.; Kolesov, V. Solid state synthesis of barium titanate in air and in supercritical water: Properties of powder and ceramics. Ceram. Int. 2019, 45, 23050-23060. [CrossRef]

34. Prado, L.R.; de Resende, N.; Silva, R.; Egues, S.M.; Banda, G. Influence of the synthesis method on the preparation of barium titanate nanoparticles. Chem. Eng. Process. Process. Intensif. 2016, 103, 12-20. [CrossRef]

35. Kržmanc, M.M.; Klement, D.; Jančar, B.; Suvorov, D. Hydrothermal conditions for the formation of tetragonal BaTiO 3 particles from potassium titanate and barium salt. Ceram. Int. 2015, 41, 15128-15137. [CrossRef]

36. Habib, A.; Haubner, R.; Stelzer, N. Effect of temperature, time and particle size of Ti precursor on hydrothermal synthesis of barium titanate. Mater. Sci. Eng. B 2008, 152, 60-65. [CrossRef]

37. Surmenev, R.; Chernozem, R.; Skirtach, A.; Bekareva, A.; Leonova, L.; Mathur, S.; Ivanov, Y.F.; Surmeneva, M. Hydrothermal synthesis of barium titanate nano/microrods and particle agglomerates using a sodium titanate precursor. Ceram. Int. 2021, 47, 8904-8914. [CrossRef]

38. Özen, M.; Mertens, M.; Snijkers, F.; Cool, P. Template-free aqueous tape casting of hydrothermally synthesized barium titanate powder and the fabrication of highly $\{001\}-\{100\}$ textured tapes. Ceram. Int. 2018, 44, 9720-9727. [CrossRef]

39. Dunne, P.W.; Starkey, C.L.; Munn, A.S.; Tang, S.V.; Luebben, O.; Shvets, I.; Ryder, A.G.; Casamayou-Boucau, Y.; Morrison, L.; Lester, E.H. Bench- and pilot-scale continuous-flow hydrothermal production of barium strontium titanate nanopowders. Chem. Eng. J. 2016, 289, 433-441. [CrossRef]

40. Magnone, E.; Kim, J.R.; Park, J.H. The effect of the hydrothermal synthesis variables on barium titanate powders. Ceram. Int. 2016, 42, 10030-10036. [CrossRef]

41. Lee, H.-W.; Moon, S.; Choi, C.-H.; Kim, D.K. Synthesis and Size Control of Tetragonal Barium Titanate Nanopowders by Facile Solvothermal Method. J. Am. Ceram. Soc. 2012, 95, 2429-2434. [CrossRef]

42. Moreno, J.; Dominguez, J.M.; Vicente, L. Synthesis and characterization of $\mathrm{MTiO}_{3}(\mathrm{M}=\mathrm{Mg}, \mathrm{Ca}, \mathrm{Sr}, \mathrm{Ba}) \mathrm{Sol}-\mathrm{Gel}$. J. Mater. Chem. 1995, 5, 509-512. [CrossRef]

43. Fuentes, S.; Zárate, R.; Chávez, E.; Muñoz, P.; Ayala, M.; Espinoza-González, R.; Leyton, P. Synthesis and characterization of $\mathrm{BaTiO}_{3}$ nanoparticles in oxygen atmosphere. J. Alloys Compd. 2010, 505, 568-572. [CrossRef]

44. Demirörs, A.; Imhof, A. $\mathrm{BaTiO}_{3}, \mathrm{SrTiO}_{3}, \mathrm{CaTiO}_{3}$, and $\mathrm{Ba}_{x} \mathrm{Sr}_{1-\mathrm{x}} \mathrm{TiO}_{3}$ Particles: A General Approach for Monodisperse Colloidal Perovskites. Chem. Mater. 2009, 21, 3002-3007. [CrossRef]

45. Zhang, X.; Cui, B.; Wang, J.; Jin, Q. The effect of a barium titanate xerogel precursor on the grain size and densification of fine-grained $\mathrm{BaTiO}_{3}$ ceramics. Ceram. Int. 2019, 45, 10626-10632. [CrossRef]

46. Fuentes, S.; Muñoz, P.; Barraza, N.; Chávez-Ángel, E.; Torres, C.M.S. Structural characterisation of slightly Fe-doped SrTiO 3 grown via a sol-gel hydrothermal synthesis. J. Sol-Gel Sci. Technol. 2015, 75, 593-601. [CrossRef]

47. Fuentes, S.; Chávez-Ángel, E.; Padilla-Campos, L.; Diaz-Droguett, D. Influence of reactant type on the Sr incorporation grade and structural characteristics of $\mathrm{Ba}_{1-\mathrm{x}} \mathrm{Sr}_{\mathrm{x}} \mathrm{TiO}_{3}(\mathrm{x}=0-1)$ grown by sol-gel-hydrothermal synthesis. Ceram. Int. 2013, 39, 8823-8831. [CrossRef]

48. Fuentes, S.; Espinoza-González, R.; Rosales, M.; León, J. Effects of Eu ${ }^{3+}$ on the morphological, structural and optical properties of BaTiO3@ZnO:Eu nanoparticles. J. Alloys Compd. 2020, 846, 156452. [CrossRef]

49. Yin, X.; Wang, S.; Wang, B.; Shen, L. Perovskite-type $\mathrm{LaMn}_{1-\mathrm{x}} \mathrm{B}_{\mathrm{x}} \mathrm{O}_{3}+\delta(\mathrm{B}=\mathrm{Fe}, \mathrm{CO}$ and $\mathrm{Ni})$ as oxygen carriers for chemical looping steam methane reforming. Chem. Eng. J. 2021, 422, 128751. [CrossRef] 
50. Yin, X.; Shen, L.; Wang, S.; Wang, B.; Shen, C. Double adjustment of Co and $\mathrm{Sr}$ in $\mathrm{LaMnO}_{3}+\delta$ perovskite oxygen carriers for chemical looping steam methane reforming. Appl. Catal. B Environ. 2021, 301, 120816. [CrossRef]

51. Mohamed, A.E.-M.A.; Álvarez-Alonso, P.; Hernando, B. The intrinsic exchange bias effect in the $\mathrm{LaMnO}_{3}$ and $\mathrm{LaFeO}_{3}$ compounds. J. Alloys Compd. 2021, 850, 156713. [CrossRef]

52. Li, Y.; Xue, L.; Fan, L.; Yan, Y. The effect of citric acid to metal nitrates molar ratio on sol-gel combustion synthesis of nanocrystalline $\mathrm{LaMnO}_{3}$ powders. J. Alloys Compd. 2009, 478, 493-497. [CrossRef]

53. Chen, Y.; Ma, J.; Li, D.; Zhu, C.; Zhang, W.; Miao, C. LaMnO 3 nanocomposite double network hydrogel electrodes with enhanced electrochemical and mechanical performance for flexible supercapacitors. J. Alloys Compd. 2021, 888, 161555. [CrossRef]

54. Li, C.; Yu, Z.; Liu, H.; Chen, K. High surface area $\mathrm{LaMnO}_{3}$ nanoparticles enhancing electrochemical catalytic activity for rechargeable lithium-air batteries. J. Phys. Chem. Solids 2018, 113, 151-156. [CrossRef]

55. Shaterian, M.; Enhessari, M.; Rabbani, D.; Asghari, M.; Salavati-Niasari, M. Synthesis, characterization and photocatalytic activity of $\mathrm{LaMnO}_{3}$ nanoparticles. Appl. Surf. Sci. 2014, 318, 213-217. [CrossRef]

56. Calvo, J.A.O.; Ayo, B.P.; De La Torre, U.; González-Velasco, J.R. Key factors in Sr-doped $\mathrm{LaBO}_{3}(\mathrm{~B}=\mathrm{Co}$ or Mn) perovskites for NO oxidation in efficient diesel exhaust purification. Appl. Catal. B Environ. 2017, 213, 198-210. [CrossRef]

57. Du, D.; Zheng, R.; He, M.; Zhao, C.; Zhou, B.; Li, R.; Xu, H.; Wen, X.; Zeng, T.; Shu, C. A-site cationic defects induced electronic structure regulation of $\mathrm{LaMnO}_{3}$ perovskite boosts oxygen electrode reactions in aprotic lithium-oxygen batteries. Energy Storage Mater. 2021, 43, 293-304. [CrossRef]

58. Yoo, H.D.; Jokisaari, J.R.; Yu, Y.-S.; Kwon, B.J.; Hu, L.; Kim, S.; Han, S.-D.; Lopez, M.; Lapidus, S.H.; Nolis, G.M.; et al. Intercalation of Magnesium into a Layered Vanadium Oxide with High Capacity. ACS Energy Lett. 2019, 4, 1528-1534. [CrossRef]

59. Cestarolli, D.T.; Guerra, E.M. Vanadium Pentoxide $\left(\mathrm{V}_{2} \mathrm{O}_{5}\right)$ : Their Obtaining Methods and Wide Applications. In Transition Metal Compounds-Synthesis, Properties, and Application; IntechOpen: London, UK, 2021.

60. Chandrappa, G.; Steunou, N.; Cassaignon, S.; Bauvais, C.; Biswas, P.; Livage, J. Vanadium Oxide: From Gels to Nanotubes. J. Sol-Gel Sci. Technol. 2003, 26, 593-596. [CrossRef]

61. O’Dwyer, C.; Lavayen, V.; Fuenzalida, D.; Newcomb, S.B.; Ana, M.A.S.; Benavente, E.; González, G.; Torres, C.M.S. Six-fold rotationally symmetric vanadium oxide nanostructures by a morphotropic phase transition. Phys. Status Solidi (b) 2007, 244, 4157-4160. [CrossRef]

62. Shao, J.; Li, X.; Qu, Q.; Zheng, H. One-step hydrothermal synthesis of hexangular starfruit-like vanadium oxide for high power aqueous supercapacitors. J. Power Sources 2012, 219, 253-257. [CrossRef]

63. Chernova, N.A.; Roppolo, M.; Dillon, A.C.; Whittingham, M.S. Layered vanadium and molybdenum oxides: Batteries and electrochromics. J. Mater. Chem. 2009, 19, 2526-2552. [CrossRef]

64. Perera, S.D.; Patel, B.; Bonso, J.; Grunewald, M.; Ferraris, J.P.; Balkus, K.J. Vanadium Oxide Nanotube Spherical Clusters Prepared on Carbon Fabrics for Energy Storage Applications. ACS Appl. Mater. Interfaces 2011, 3, 4512-4517. [CrossRef]

65. O’Dwyer, C.; Navas, D.; Lavayen, V.; Benavente, E.; Santa Ana, M.A.; Gonzalez, G.; Newcomb, S.B.; Sotomayor Torres, C.M. Nano-Urchin: The Formation and Structure of High-Density Spherical Clusters of Vanadium Oxide Nanotubes. Chem. Mater. 2006, 18, 3016-3022. [CrossRef]

66. Ma, Y.; Wu, M.; Jin, X.; Shu, R.; Hu, C.; Xu, T.; Li, J.; Meng, X.; Cao, X. $\left(\mathrm{NH}_{4}\right)_{2} \mathrm{~V}_{7} \mathrm{O}_{16}$ Microbricks as a Novel Anode for Aqueous Lithium-Ion Battery with Good Cyclability. Chem.-A Eur. J. 2021, 27, 12341-12351. [CrossRef]

67. Heo, J.W.; Bu, H.; Hyoung, J.; Hong, S.-T. Ammonium Vanadium Bronze, (NH4)2V7O16, as a New Lithium Intercalation Host Material. Inorg. Chem. 2020, 59, 4320-4327. [CrossRef] [PubMed]

68. Navas, D.; Donoso, J.P.; Magon, C.; Sotomayor-Torres, C.M.; Moreno, M.; Lozano, H.; Benavente, E.; González, G. Ammonium hexadeca-oxo-heptavanadate microsquares. A new member in the family of the V7O16 mixed-valence nanostructures. New $\mathrm{J}$. Chem. 2019, 43, 17548-17556. [CrossRef]

69. Sabir, S.; Arshad, M.; Chaudhari, S.K. Zinc Oxide Nanoparticles for Revolutionizing Agriculture: Synthesis and Applications. Sci. World J. 2014, 2014, 1-8. [CrossRef]

70. Narayana, A.; Bhat, S.A.; Fathima, A.; Lokesh, S.V.; Surya, S.G.; Yelamaggad, C.V. Green and low-cost synthesis of zinc oxide nanoparticles and their application in transistor-based carbon monoxide sensing. RSC Adv. 2020, 10, 13532-13542. [CrossRef]

71. Shaba, E.Y.; Jacob, J.O.; Tijani, J.O.; Suleiman, M.A.T. A critical review of synthesis parameters affecting the properties of zinc oxide nanoparticle and its application in wastewater treatment. Appl. Water Sci. 2021, 11, 1-41. [CrossRef]

72. Di Marcantonio, M.; Gellner, S.; Namanga, J.E.; Frohleiks, J.; Gerlitzki, N.; Vollkommer, F.; Bacher, G.; Nannen, E. Performance Enhancement by ZnO Nanoparticle Layer in Hybrid Ionic Transition Metal Complex-Light-Emitting Electrochemical Cells (iTMC-LECs). Adv. Mater. Technol. 2017, 2, 1600215. [CrossRef]

73. Wibowo, A.; Marsudi, M.A.; Amal, M.I.; Ananda, M.B.; Stephanie, R.; Ardy, H.; Diguna, L.J. ZnO nanostructured materials for emerging solar cell applications. RSC Adv. 2020, 10, 42838-42859. [CrossRef]

74. Dodoo-Arhin, D.; Asiedu, T.; Agyei-Tuffour, B.; Nyankson, E.; Obada, D.; Mwabora, J. Photocatalytic degradation of Rhodamine dyes using zinc oxide nanoparticles. Mater. Today Proc. 2020, 38, 809-815. [CrossRef]

75. Kołodziejczak-Radzimska, A.; Jesionowski, T. Zinc Oxide-From Synthesis to Application: A Review. Materials 2014, 7, $2833-2881$. [CrossRef] [PubMed] 
76. Aal, N.A.; Al-Hazmi, F.; Al-Ghamdi, A.A.; A Alghamdi, A.; El-Tantawy, F.; Yakuphanoglu, F. Novel rapid synthesis of zinc oxide nanotubes via hydrothermal technique and antibacterial properties. Spectrochim. Acta Part A Mol. Biomol. Spectrosc. 2015, 135, 871-877. [CrossRef]

77. Manikandan, B.; Endo, T.; Kaneko, S.; Murali, K.R.; John, R. Properties of sol gel synthesized ZnO nanoparticles. J. Mater. Sci. Mater. Electron. 2018, 29, 9474-9485. [CrossRef]

78. Galdámez-Martinez, A.; Santana, G.; Güell, F.; Martínez-Alanis, P.R.; Dutt, A. Photoluminescence of ZnO Nanowires: A Review. Nanomater. 2020, 10, 857. [CrossRef] [PubMed]

79. Meenakshi, G.; Sivasamy, A. Synthesis and characterization of zinc oxide nanorods and its photocatalytic activities towards degradation of 2,4-D. Ecotoxicol. Environ. Saf. 2017, 135, 243-251. [CrossRef]

80. Navas, D.; Ibañez, A.; González, I.; Palma, J.L.; Dreyse, P. Controlled dispersion of ZnO nanoparticles produced by basic precipitation in solvothermal processes. Heliyon 2020, 6, e05821. [CrossRef]

81. Nagar, A.; Kumar, A.; Parveen, S.; Kumar, A.; Dhasmana, H.; Husain, S.; Verma, A.; Jain, V. Zinc oxide nanoflowers synthesized by sol-gel technique for field emission displays (FEDs). Mater. Today Proc. 2020, 32, 402-406. [CrossRef]

82. Kiriarachchi, H.D.; Abouzeid, K.M.; Bo, L.; El-Shall, M.S. Growth Mechanism of Sea Urchin ZnO Nanostructures in Aqueous Solutions and Their Photocatalytic Activity for the Degradation of Organic Dyes. ACS Omega 2019, 4, 14013-14020. [CrossRef]

83. Cheng, J.H.; Xu, S.; Ding, C.H. Uniform Nano/Micron-Sized ZnO Spheres with Controllable Diameter. Adv. Mater. Res. 2012, 496, 268-271. [CrossRef]

84. Pourrahimi, A.M.; Liu, D.; Pallon, L.K.H.; Andersson, R.L.; Abad, A.M.; Lagarón, J.-M.; Hedenqvist, M.S.; Ström, V.; Gedde, U.W.; Olsson, R.T. Water-based synthesis and cleaning methods for high purity ZnO nanoparticles—comparing acetate, chloride, sulphate and nitrate zinc salt precursors. RSC Adv. 2014, 4, 35568-35577. [CrossRef]

85. Samei, M.; Sarrafzadeh, M.-H.; Faramarzi, M.A. The impact of morphology and size of zinc oxide nanoparticles on its toxicity to the freshwater microalga, Raphidocelis subcapitata. Environ. Sci. Pollut. Res. 2018, 26, 2409-2420. [CrossRef]

86. Anand, K.; Varghese, S.; Krishnamoorthy, A. Role of surfactants on the stability of nano-zinc oxide dispersions. Part. Sci. Technol. 2015, 35, 67-70. [CrossRef]

87. Wu, P.-Y.; Pike, J.; Zhang, F.; Chan, S.-W. Low-Temperature Synthesis of Zinc Oxide Nanoparticles. Int. J. Appl. Ceram. Technol. 2006, 3, 272-278. [CrossRef]

88. Chieng, B.W.; Loo, Y.Y. Synthesis of ZnO nanoparticles by modified polyol method. Mater. Lett. 2012, 73, 78-82. [CrossRef]

89. Karak, N.; Barik, P.; Kundu, T.K. Visible luminescence from triethanolamine-modified zinc oxide nanoparticles. In AIP Conference Proceedings; American Institute of Physics: College Park, MD, USA, 2013; pp. 181-182.

90. Tseng, Y.-K.; Chuang, M.-H.; Chen, Y.-C.; Wu, C.-H. Synthesis of 1D, 2D, and 3D ZnO Polycrystalline Nanostructures Using the Sol-Gel Method. J. Nanotechnol. 2012, 2012, 712850. [CrossRef]

91. Haque, J.; Bellah, M.; Hassan, R.; Rahman, S. Synthesis of ZnO nanoparticles by two different methods \& comparison of their structural, antibacterial, photocatalytic and optical properties. Nano Express 2020, 1, 010007. [CrossRef]

92. Shokuhfar, A.; Samei, J.; Kandjani, A.E.; Vaezi, M.R. Synthesis of ZnO Nanoparticles via Sol-Gel Process Using Triethanolamine as a Novel Surfactant. Defect Diffus. Forum 2008, 273-276, 626-631. [CrossRef]

93. Haque, A.; Mahalakshmi, S. Effect of Triethanolamine on Zinc Oxide Nanoparticles. Mater. Focus 2013, 2, 469-474. [CrossRef]

94. Liu, X.; Wang, C.; Cai, B.; Xiao, X.; Guo, S.; Fan, Z.; Li, J.; Duan, X.; Liao, L. Rational Design of Amorphous Indium Zinc Oxide/Carbon Nanotube Hybrid Film for Unique Performance Transistors. Nano Lett. 2012, 12, 3596-3601. [CrossRef]

95. Shao, D.; Wei, Q.; Zhang, L.; Cai, Y.; Jiang, S. Surface functionalization of carbon nanofibers by sol-gel coating of zinc oxide. Appl. Surf. Sci. 2008, 254, 6543-6546. [CrossRef]

96. Han, T.Y.-J.; Worsley, M.A.; Baumann, T.F.; Satcher, J.J.H. Synthesis of ZnO coated activated carbon aerogel by simple sol-gel route. J. Mater. Chem. 2011, 21, 330-333. [CrossRef]

97. Zhou, X.; Wu, G.; Wu, J.; Yang, H.; Wang, J.; Gao, G. Carbon black anchored vanadium oxide nanobelts and their post-sintering counterpart $\left(\mathrm{V}_{2} \mathrm{O}_{5}\right.$ nanobelts) as high performance cathode materials for lithium ion batteries. Phys. Chem. Chem. Phys. 2014, 16, 3973-3982. [CrossRef]

98. Zhou, X.; Wu, G.; Gao, G.; Cui, C.; Yang, H.; Shen, J.; Zhou, B.; Zhang, Z. The synthesis, characterization and electrochemical properties of Multi-Wall Carbon Nanotube-induced vanadium oxide nanosheet composite as a novel cathode material for lithium ion batteries. Electrochim. Acta 2012, 74, 32-38. [CrossRef]

99. Kim, I.-H.; Kim, J.-H.; Cho, B.W.; Lee, Y.-H.; Kim, K.-B. Synthesis and Electrochemical Characterization of Vanadium Oxide on Carbon Nanotube Film Substrate for Pseudocapacitor Applications. J. Electrochem. Soc. 2006, 153, A989-A996. [CrossRef]

100. Kumar, A. Sol gel synthesis of zinc oxide nanoparticles and their application as nano-composite electrode material for supercapacitor. J. Mol. Struct. 2020, 1220, 128654. [CrossRef]

101. Bar-Cohen, Y. Biomimetics—using nature to inspire human innovation. Bioinspir. Biomim. 2006, 1, P1-P12. [CrossRef]

102. Gao, F.; Qu, J.; Zhao, Z.; Wang, Z.; Qiu, J. Nitrogen-doped activated carbon derived from prawn shells for high-performance supercapacitors. Electrochim. Acta 2016, 190, 1134-1141. [CrossRef]

103. Redondo, E.; Carretero-González, J.; Goikolea, E.; Ségalini, J.; Mysyk, R. Effect of pore texture on performance of activated carbon supercapacitor electrodes derived from olive pits. Electrochim. Acta 2015, 160, 178-184. [CrossRef]

104. Li, B.; Dai, F.; Xiao, Q.; Yang, L.; Shen, J.; Zhang, C.; Cai, M. Nitrogen-doped activated carbon for a high energy hybrid supercapacitor. Energy Environ. Sci. 2016, 9, 102-106. [CrossRef] 
105. Wang, C.; Wang, X.; Lu, H.; Li, H.; Zhao, X. Cellulose-derived hierarchical porous carbon for high-performance flexible supercapacitors. Carbon 2018, 140, 139-147. [CrossRef]

106. Maiti, U.N.; Lim, J.; Lee, K.E.; Lee, W.J.; Kim, S.O. Three-Dimensional Shape Engineered, Interfacial Gelation of Reduced Graphene Oxide for High Rate, Large Capacity Supercapacitors. Adv. Mater. 2013, 26, 615-619. [CrossRef]

107. Cao, X.; Yin, Z.; Zhang, H. Three-dimensional graphene materials: Preparation, structures and application in supercapacitors. Energy Environ. Sci. 2014, 7, 1850-1865. [CrossRef]

108. Yu, Z.; Tetard, L.; Zhai, L.; Thomas, J. Supercapacitor electrode materials: Nanostructures from 0 to 3 dimensions. Energy Environ. Sci. 2015, 8, 702-730. [CrossRef]

109. Wen, P.; Gong, P.; Sun, J.; Wang, J.; Yang, S. Design and synthesis of Ni-MOF/CNT composites and rGO/carbon nitride composites for an asymmetric supercapacitor with high energy and power density. J. Mater. Chem. A 2015, 3, 13874-13883. [CrossRef]

110. Ding, B.; Guo, D.; Wang, Y.; Wu, X.; Fan, Z. Functionalized graphene nanosheets decorated on carbon nanotubes networks for high performance supercapacitors. J. Power Sources 2018, 398, 113-119. [CrossRef]

111. Biswal, M.; Banerjee, A.; Deo, M.; Ogale, S. From dead leaves to high energy density supercapacitors. Energy Environ. Sci. 2013, 6, 1249-1259. [CrossRef]

112. Abioye, A.M.; Ani, F.N. Advancement in the production of activated carbon from biomass using microwave heating. J. Teknol. 2017, 79, 79-88. [CrossRef]

113. Lu, B.; Xiao, Z.; Zhu, H.; Xiao, W.; Wu, W.; Wang, D. Enhanced capacitive properties of commercial activated carbon by re-activation in molten carbonates. J. Power Sources 2015, 298, 74-82. [CrossRef]

114. Hu, Y.; Tong, X.; Zhuo, H.; Zhong, L.; Peng, X. Biomass-Based Porous N-Self-Doped Carbon Framework/Polyaniline Composite with Outstanding Supercapacitance. ACS Sustain. Chem. Eng. 2017, 5, 8663-8674. [CrossRef]

115. Yan, J.; Wang, Q.; Wei, T.; Fan, Z. Recent Advances in Design and Fabrication of Electrochemical Supercapacitors with High Energy Densities. Adv. Energy Mater. 2014, 4, 1300816. [CrossRef]

116. Chen, X.; Paul, R.; Dai, L. Carbon-based supercapacitors for efficient energy storage. Natl. Sci. Rev. 2017, 4, 453-489. [CrossRef]

117. Hao, P.; Zhao, Z.; Tian, J.; Li, H.; Sang, Y.; Yu, G.; Cai, H.; Liu, H.; Wong, C.P.; Umar, A. Hierarchical porous carbon aerogel derived from bagasse for high performance supercapacitor electrode. Nanoscale 2014, 6, 12120-12129. [CrossRef]

118. Xu, M.; Yu, Q.; Liu, Z.; Lv, J.; Lian, S.; Hu, B.; Mai, L.; Zhou, L. Tailoring porous carbon spheres for supercapacitors. Nanoscale 2018, 10, 21604-21616. [CrossRef] [PubMed]

119. Liu, S.; Cai, Y.; Zhao, X.; Liang, Y.; Zheng, M.; Hu, H.; Dong, H.; Jiang, S.; Liu, Y.; Xiao, Y. Sulfur-doped nanoporous carbon spheres with ultrahigh specific surface area and high electrochemical activity for supercapacitor. J. Power Sources 2017, 360, 373-382. [CrossRef]

120. Liu, H.; Zhang, Y.; Ke, Q.; Ho, K.H.; Hu, Y.; Wang, J. Tuning the porous texture and specific surface area of nanoporous carbons for supercapacitor electrodes by adjusting the hydrothermal synthesis temperature. J. Mater. Chem. A 2013, 1, 12962-12970. [CrossRef]

121. Wang, J.; Shen, L.; Ding, B.; Nie, P.; Deng, H.; Dou, H.; Zhang, X. Fabrication of porous carbon spheres for high-performance electrochemical capacitors. RSC Adv. 2014, 4, 7538-7544. [CrossRef]

122. Hu, B.; Wang, K.; Wu, L.; Yu, S.-H.; Antonietti, M.; Titirici, M.-M. Engineering Carbon Materials from the Hydrothermal Carbonization Process of Biomass. Adv. Mater. 2010, 22, 813-828. [CrossRef] [PubMed]

123. Pan, L.; Wang, Y.; Hu, H.; Li, X.; Liu, J.; Guan, L.; Tian, W.; Wang, X.; Li, Y.; Wu, M. 3D self-assembly synthesis of hierarchical porous carbon from petroleum asphalt for supercapacitors. Carbon 2018, 134, 345-353. [CrossRef]

124. Liu, M.-C.; Lu, C.; Xu, Y.; Hu, Y.-X.; Li, J.; Zhang, H.; Zhang, Y.-S.; Zhang, B.-M.; Kong, L.-B.; Liu, W.-W.; et al. ThreeDimensional Interconnected Reticular Porous Carbon From Corn Starch By a Sample Sol-Gel Method Toward High-Performance Supercapacitors With Aqueous and Ionic Liquid Electrolytes. ACS Sustain. Chem. Eng. 2019, 7, 18690-18699. [CrossRef] 